\title{
Understanding $\mathrm{N} 2 \mathrm{O}$ formation mechanisms through sensitivity analyses using a plant-
} wide benchmark simulation model

\author{
Boiocchi, Riccardo; Gernaey, Krist; Sin, Gürkan
}

Published in:

Chemical Engineering Journal

Link to article, DOI:

10.1016/j.cej.2017.02.091

Publication date:

2017

Document Version

Peer reviewed version

Link back to DTU Orbit

Citation (APA):

Boiocchi, R., Gernaey, K., \& Sin, G. (2017). Understanding N O formation mechanisms through sensitivity analyses using a plant-wide benchmark simulation model. Chemical Engineering Journal, 317, 935-951. https://doi.org/10.1016/j.cej.2017.02.091

\section{General rights}

Copyright and moral rights for the publications made accessible in the public portal are retained by the authors and/or other copyright owners and it is a condition of accessing publications that users recognise and abide by the legal requirements associated with these rights.

- Users may download and print one copy of any publication from the public portal for the purpose of private study or research.

- You may not further distribute the material or use it for any profit-making activity or commercial gain

- You may freely distribute the URL identifying the publication in the public portal 


\title{
Understanding $\mathrm{N}_{2} \mathrm{O}$ formation mechanisms through sensitivity
}

\section{analyses using a plant-wide benchmark simulation model}

\author{
Riccardo Boiocchi*, Krist V. Gernaey* and Gürkan Sin*(a) \\ *CAPEC-PROCESS Research Center, Technical University of Denmark, Kgs. Lyngby (2800), Denmark \\ (a) Corresponding author, email: gsi@kt.dtu.dk.
}

\begin{abstract}
In the present work, sensitivity analyses are performed on a plant-wide model incorporating the typical treatment unit of a full-scale wastewater treatment plant and $\mathrm{N}_{2} \mathrm{O}$ production and emission dynamics. The influence of operating temperature is investigated. The results are exploited to identify the biological mechanisms responsible for $\mathrm{N}_{2} \mathrm{O}$ emissions, $\mathrm{TN}$ removal efficiency, competition for oxygen among the different microbial groups and the trade-off between oxygen consumption and effluent nitrogen loading. It was found that $\mathrm{N}_{2} \mathrm{O}$ emissions are triggered by poor oxygenation levels which cause an imbalance in the activity of NOB over the activity of AOB. As a matter of fact this imbalance leads to nitrite accumulation which in turn triggers AOB denitrification. This is particularly true at high temperatures, due to higher difference between AOB and NOB specific growth rates. At the same time, too high oxygen availability is found to inhibit heterotrophic denitrification, leading to incomplete reduction of nitrogen oxides and thereby to an accumulation of nitrous oxide. High oxygen supply is also found to worsen effluent quality via inhibition of heterotrophic denitrification. Low temperatures have shown to drastically limit aerobic AOB activity, thus compromising effluent quality. Finally, the organic biodegradable carbon surplus leaving the
\end{abstract}


anoxic zone is identified to slow down NOB activity via oxygen competition with heterotrophs in the aerobic zone. With regard to the control strategy for the minimization of $\mathrm{N}_{2} \mathrm{O}$ emissions, the ratio between nitrate produced and ammonium consumed in an aerobic zone should be considered as candidate controlled variable to check whether nitrification is complete or nitrites are building up. Oxygen availability should be regulated according to the measured controlled variable.

Keywords: nitrous oxide, sensitivity analysis, Morris screening, Monte Carlo, wastewater.

\section{Introduction}

Nitrous oxide $\left(\mathrm{N}_{2} \mathrm{O}\right)$ is a greenhouse gas with a global warming potential (GWP) three hundred times stronger than carbon dioxide. Several measurement campaigns have found that $\mathrm{N}_{2} \mathrm{O}$ is being emitted from domestic wastewater treatment plants (WWTPs) in a variable amount according to plant configuration and operating conditions [1-6]. Given its strong GWP, control strategies reducing $\mathrm{N}_{2} \mathrm{O}$ emissions become necessary with the aim of reducing the WWTP carbon footprint. $\mathrm{N}_{2} \mathrm{O}$ is typically produced during the nitrogen removing biological processes, namely autotrophic nitrification and heterotrophic denitrification. There are specific environmental conditions triggering $\mathrm{N}_{2} \mathrm{O}$ production, and knowing them is essential for the development of $\mathrm{N}_{2} \mathrm{O}$-minimizinig control strategies. In full-scale WWT systems where different microbial communities coexist, the amount of $\mathrm{N}_{2} \mathrm{O}$ produced does not solely depend on the kinetics of a single microbial group but also on the interactions among the different biological processes. For this reason, observations from laboratory experiences, where a single microbial group is selected, are considered not to be enough. On the other hand, full-scale measurements have only been able to guess which pathway is more important for the specific plant studied, but have not allowed formulating a generic framework for reducing $\mathrm{N}_{2} \mathrm{O}$ emissions on the basis of the understanding of underlying microbiological interactions in WWTPs.

Sensitivity analyses on the $\mathrm{N}_{2} \mathrm{O}$ emissions predicted by a model describing a full-scale WWTP where different microbial communities interact can represent an efficient tool for the identification of those 
environmental conditions minimizing $\mathrm{N}_{2} \mathrm{O}$ production. Sensitivity analyses are in fact used to have an overview of how the uncertainties of inputs to a model affect the model output. The results from these analyses often enable identifying the most influential model parameters on the predictions of a model, but can actually also be used further to track the main driving forces determining the model outputs that are analysed, such as $\mathrm{N}_{2} \mathrm{O}$ emissions.

The present work uses this property of the sensitivity analysis framework to identify the optimal environmental conditions and the microbial interactions to be established thereby for the reduction of $\mathrm{N}_{2} \mathrm{O}$ emissions in a plant-wide model, where different treatment units are considered and multiple biological processes performed by the typical microbial groups such as AOB, NOB and HB interact. The model used is the Benchmark Simulation Model $\mathrm{n}^{0} 2$ for Nitrous oxide (BSM2N) presented in Boiocchi et al. [7]. The BSM2N is an extension of the BSM2 platform by Jeppsson et al. [8] with processes for $\mathrm{N}_{2} \mathrm{O}$ production by Guo and Vanrolleghem [9]. On this model, two sensitivity analyses are performed: one investigating the effect of operating conditions such as oxygen mass transfer coefficient and influent ammonium on the $\mathrm{N}_{2} \mathrm{O}$ emissions keeping the parameters at their default value, and another investigating the effect of model parameter uncertainties on the $\mathrm{N}_{2} \mathrm{O}$ emissions, keeping the operating conditions such as oxygen and total suspended solids fixed.

Besides analysing the quantity of $\mathrm{N}_{2} \mathrm{O}$ emitted, and considering that minimizing $\mathrm{N}_{2} \mathrm{O}$ has to be performed in such a way that the effluent respects discharge limits, the sensitivity analyses mentioned before will also be carried out on the total nitrogen removal efficiency as model output. In addition, the sensitivity to process parameters of the oxygen consumption by the different groups of microorganisms will be analysed in order to obtain further insights regarding the interactions among the microbial communities. Moreover, the ratio between oxygen consumed and total nitrogen removal efficiency will be included among the outputs analysed in order to have an indication of the trade-off between aeration energy consumption and effluent quality.

All the analyses are performed at different operating temperatures to investigate the effect of seasonal variation. 
Based on the results achieved from the sensitivity analyses, a generic control idea for reducing $\mathrm{N}_{2} \mathrm{O}$ emissions will be formulated.

\section{Material and methods}

In this section, first the description of the model used will be provided (Section 2.1). Secondly, the two sensitivity analyses are presented in more detail: the first will investigate the effect of operating conditions (Section 2.2), while the second will investigate the effect of model parameter uncertainties (Section 2.3) according to two procedures: the Monte Carlo procedure and the Morris screening procedure.

\subsection{The model}

The Benchmark Simulation Model $n^{0} 2$ for Nitrous oxide (BSM2N) was developed by Boiocchi et al. [7]. The model was obtained by adopting the Activated Sludge Model for Greenhouse gases $n^{0} 1$ (ASMG1) as new model for the biological processes in the main activate sludge unit of the BSM2, whose layout is presented in Figure 1. As can be seen, the layout consists of a main and a side stream. In the mainstream, the primary sludge is removed from sewage water through a primary clarifier (PRIM). The water effluent from PRIM is carried to a biological zone of predenitrification, with two anoxic tanks (ANOX1 and ANOX2) followed by three aerobic tanks (AER1, AER2 and AER3). The biologically-treated water passes into a secondary clarifier (SEC2). The wastage sludge from SEC2 and the primary sludge settled in PRIM are then treated in a side stream, where the sludge, after being separated from the water in a thickener (THK), is anaerobically treated in an anaerobic digester (AD) and subsequently dewatered in DW. The influent used is taken from Gernaey et al. [10].

A graphical representation of the main model processes of the ASMG1 is given in Figure 2 (where $\mathrm{CH}_{2} \mathrm{O}$ is the simplified chemical formula for the organic biodegradable substrate) whereas Tables (A.1-A.3) in the Appendix show their stoichiometry and kinetics. As can be seen in Figure 2, the ASM1 HB denitrification, modelled as one-step process, is replaced with the four-step HB denitrification from the Activated Sludge 
Model for Nitrogen (ASMN) developed by Hiatt and Grady [11]. More specifically, in the ASMN, the ASM1 reduction of nitrate and nitrite nitrogen to dinitrogen is split up into four sequential processes: (I) nitrate reduction to nitrite, (II) nitrite reduction to nitric oxide, (III) nitric oxide reduction to nitrous oxide, and (IV) nitrous oxide to dinitrogen. With regard to AOB denitrification, the model uses a modified version of the processes proposed by Mampaey et al. [12]. In particular, AOB denitrification is modelled as a twostep process where nitrous oxide is produced as a result of enzymatic reduction of nitrite via nitric oxide during the oxidation of ammonium. A limited amount of oxygen is used as well because hydroxylamine $\left(\mathrm{NH}_{2} \mathrm{OH}\right)$, obligatorily produced by AOB with oxygen, is the true substrate used during AOB denitrification. The function used to include the effect of the oxygen concentration on the rate is a Haldane-type kinetics, where oxygen is enhancing AOB denitrification only for low concentrations (between 0 and $0.65 \mathrm{mg}$ (COD). $\mathrm{L}^{-1}$ ) where the concentration of the substrate $\mathrm{NH}_{2} \mathrm{OH}$ increases. At higher concentrations (above 0.65 mg (-COD). $\mathrm{L}^{-1}$ ) AOB are modelled to be increasingly inhibited to use nitrite for the oxidation of $\mathrm{NH}_{2} \mathrm{OH}$; hence, oxygen has an inhibiting effect. AOB are assumed to grow during both their aerobic and their anoxic activity. The model was calibrated by Guo and Vanrolleghem [9] in order to fit the liquid predictions to the ones given by the Activated Sludge Model No. 1 by Henze et al. [13]. The parameter values of the $\mathrm{N}_{2} \mathrm{O}$ producing processes were determined by fixing the plant $\mathrm{N}_{2} \mathrm{O}$ emission factor to a constant value taken from literature. Although the quantification of $\mathrm{N}_{2} \mathrm{O}$ emissions by the ASMG1 may not be considered reliable, the model structure can still be used to describe how $\mathrm{N}_{2} \mathrm{O}$ behaves as a function of the operating conditions. Model calibrations with respect to $\mathrm{N}_{2} \mathrm{O}$ production and emission in a full-scale context are rather challenging as demonstrated by Sperandio et al. [14] and can be quite specific to the particular operation of the plant, as described by Ni et al. [15]. On the other hand, models calibrated according to experimental data may present incompatibilities when incorporated together with other processes for plant-wide purposes, as explained in Snip et al. [16]. At this stage of research, though desirable, it is not possible to have a full-scale model quantifying reliably all the $\mathrm{N}_{2} \mathrm{O}$ produced. Nevertheless, it is possible to understand what the main operating processes minimizing the $\mathrm{N}_{2} \mathrm{O}$ production are and thus to build up control strategies aimed at plant carbon footprint reduction. 




Figure 1: Layout of the Benchmark Simulation Model n²2 by Jeppsson et al. [8].

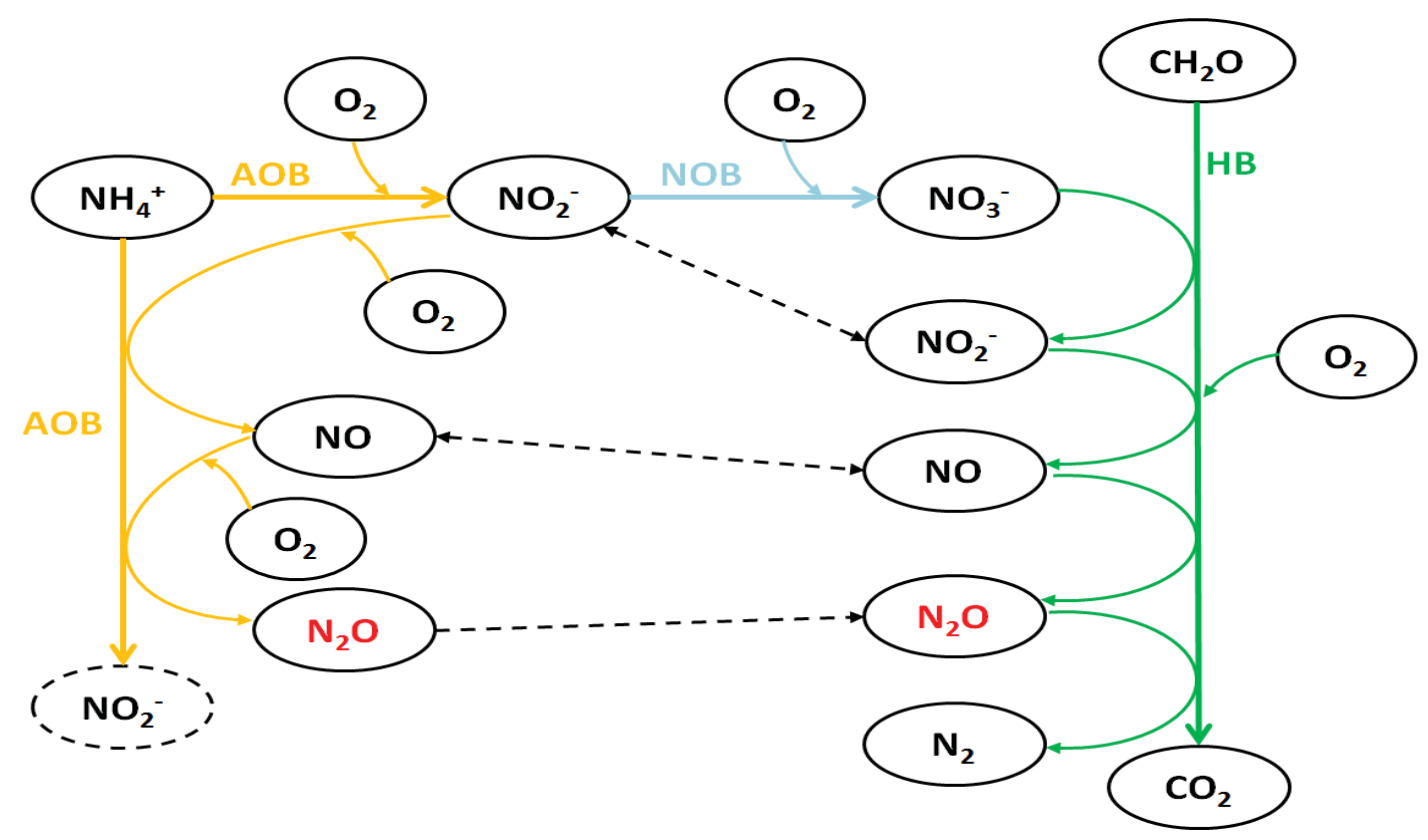

Figure 2: Main biological processes modelled in the ASMG1 by Guo and Vanrolleghem [9].

\subsection{Sensitivity analysis for operating conditions: input-output mapping}

The first sensitivity analysis is carried out by perturbing operating conditions, considering a full-factorial design in order to study the systems response to the inputs, i.e. input-output mapping. This is done as 
follows: the oxygen mass transfer coefficients of the three aerobic reactors $\left(\mathrm{k}_{\mathrm{L}} \mathrm{a}_{\mathrm{AER}}\right)$ of Figure 1 and the influent ammonium concentration are varied between a lower and an upper boundary. In particular, the $\mathrm{k}_{\mathrm{L}} \mathrm{a}_{\mathrm{AER}}$ is varied between a minimum value of $5 \mathrm{~d}^{-1}$ and a maximum value of $360 \mathrm{~d}^{-1}$, using a fixed interval of $5 \mathrm{~d}^{-1}$, whereas the influent ammonium concentration was varied between a minimum value of $5 \mathrm{mg}$ N.L $\mathrm{L}^{-1}$ and a maximum value of $70 \mathrm{mg} \mathrm{N} . \mathrm{L}^{-1}$, with a fixed interval of $5 \mathrm{mg} \mathrm{N} . \mathrm{L}^{-1}$. Full-factorial combinations between $\mathrm{k}_{\mathrm{L}} \mathrm{a}_{\mathrm{AER}}$ and $\mathrm{NH}_{4}{ }^{+}$then form the $\mathrm{k}_{\mathrm{L}} \mathrm{a}_{\mathrm{AER}}-\mathrm{NH}_{4}{ }^{+}$samples. For the sake of simplicity the same value of $\mathrm{k}_{\mathrm{L}} \mathrm{a}_{\mathrm{AER}}$ was here used for the three aerobic tanks. The $\mathrm{k}_{\mathrm{L}} \mathrm{a}_{\mathrm{AER}}-\mathrm{NH}_{4}{ }^{+}$samples identified are then used for steady-state simulations of the BSM2N.

\subsection{Sensitivity analysis for parameter uncertainties}

The observations from the first sensitivity analysis are attempted to be verified and improved through a secondary sensitivity analysis investigating the propagation of the model parameter uncertainties to the predicted outputs. In this regard, two different sensitivity analysis methods will be used: the Monte Carlo procedure and the Morris Screening procedure.

\section{Monte Carlo procedure}

In order to present in mathematical terms the Monte Carlo approach, the notational conventions below are used.

First of all, the mathematical model is represented by the following equations:

$$
\begin{gathered}
\frac{d \underline{x}}{d t}=f(t, \underline{x}, \underline{u}, \underline{P}) \\
\underline{x}\left(t_{0}\right)=\underline{x_{0}} \\
\underline{y}=g(\underline{x}(t))
\end{gathered}
$$

In Eqns. (1-3) $t$ is the time, $\underline{x}$ is the vector of state variables, $\underline{x}_{0}$ is the vector of initial states, $\underline{u}$ is the vector of input variables, $\underline{P}$ is the vector of input parameters and $y$ is the vector of output variables. 
The sensitivity analysis according to the Monte Carlo procedure is performed according to the steps represented in Figure A1 (see Supplementary Information (SI)). As can be seen, the first step is to assign a proper range/uncertainty to the model inputs ( $\underline{u}$ and/or $\underline{P}$ ) and to consider eventual correlations between them. Afterwards, different input samples are produced using the Latin Hypercube Sampling (LHS) technique with correlation control according to Iman and Conover [17]. The sampling matrix $\underline{\theta}$, having a number of rows equal to the number of samples and a number of columns equal to the number of uncertain inputs, is then obtained. For each sample, a different model simulation is performed and different values of model outputs $(y)$ are thereby obtained. Mean values $(\mu)$ and standard deviations $(\sigma)$ of these outputs are then calculated according to Eqns. (4-5) and the ratio between them $(\sigma / \mu)$ is used to evaluate the uncertainty of the model predictions. The higher the ratio is, the higher the uncertainty of the output prediction is considered. Values of $\sigma$-to- $\mu$ ratio equal or higher than unity are considered to indicate clearly high uncertainty of the predicted output, i.e. high propagation of input uncertainties to output predictions. Afterwards, a linear regression between each of the model simulation results and the set of uncertain inputs (Eqn. (6)) is performed. The regression is considered to be reliable if the coefficient of determination $\left(\mathrm{R}^{2}\right)$ between output values obtained from simulation and the corresponding linearized ones is equal to or higher than 0.7. The regression coefficients found for each uncertain input are then standardized according to Eqn. (7) in order to identify an unbiased measure for the impact of each uncertain input on the output with regard to the uncertainty of the inputs and of predicted outputs.

The sensitivity of all those outputs which could not be reliably linearized with respect to the uncertain inputs (i.e. the $\mathrm{R}^{2}$ resulted too low) was analysed through the Morris screening procedure, presented in the next subsection.

$$
\begin{gathered}
\mu(y)=\frac{\sum_{j=1}^{N} y^{j}}{N} \\
\sigma(y)=\sqrt{\frac{1}{N} \cdot \sum_{j=1}^{N}\left(y^{j}-\mu(y)\right)^{2}} \\
y_{\text {lin }, \text { reg }}=a+\sum_{i}\left(b_{i} \cdot \theta_{i}\right)
\end{gathered}
$$




$$
\beta_{i}=\frac{\sigma\left(\theta_{i}\right)}{\sigma(y)} \cdot b_{i}
$$

\section{Morris screening procedure}

As mentioned before, for those outputs which cannot be accurately regressed linearly, the Morris screening procedure, whose steps are depicted in Figure A2 (see SI), is here used instead of the MC procedure. As can be seen, the procedure consists first in assigning the input uncertainty. Afterwards, the number of levels into which the input space $(p)$ needs to be divided is decided, and thus the optimal perturbation factor $(\Delta)$ can be identified according to Eqn. (8). On the basis of a predefined number of repetitions for the calculation of the elementary effects and of $\Delta$, the sampling according to the procedure by Morris [18] is performed. The sampling matrix $\underline{\theta}$ is thus obtained. For each input sample a different model simulation is performed. The simulation outputs are then used to calculate the elementary effects (EEs) at specific input points according to Eqn. (9). The EEs are then standardized by using the standard deviations of the uncertain input $\left(\sigma_{\theta_{i}}\right)$ and the standard deviation of the output $\left(\sigma_{y}\right)$ resulting from the Monte Carlo simulations according to Sin and Gernaey [19] (see Eqn. (10)). Mean and standard deviation of the standardized elementary effects (SEE) are then calculated. The ranking of the impact of the parameters on each output is performed by comparing the mean of the SEE of those parameters having a standard deviation lower than the standard error of the mean (SEMi), which is calculated by dividing the standard deviation of the standardised elementary effect of a particular parameter by the squared root of the total number of points according to which the input space is split up (Eqn. (11)).

$$
\begin{gathered}
\Delta=\frac{p}{2 \cdot(p-1)} \\
E E_{i}^{j}=\frac{y\left(\theta_{1}^{j}, \theta_{2}^{j}, \ldots \ldots, \theta_{i}^{j}+\Delta_{O P T}, \ldots \ldots, \theta_{m-1}^{j}, \theta_{m}^{j}\right)-y\left(\underline{\theta}^{j}\right)}{\Delta} \\
S E E_{i}^{j}=E E_{i}^{j} \cdot \frac{\sigma_{\theta_{i}}}{\sigma_{y}} \\
S E M_{i}= \pm \frac{\sigma\left(S E E_{i}^{j}\right)}{\sqrt{r}}
\end{gathered}
$$




\section{Parameter uncertainties}

For both the Monte Carlo and the Morris screening sampling, following the examples by Sin et al. [20] and Vangsgaard et al. [21], the ASMG1 parameters are ranked according to the following uncertainty classes:

- CLASS 1: 5\% uncertainty,

- CLASS 2: 25\% uncertainty,

- CLASS 3: 50\% uncertainty,

- $\quad$ CLASS 4: 100\% uncertainty.

More in detail, yield coefficients for the different microbial groups and the half-saturation coefficient for hydrolysis of slowly-biodegradable organics $\left(\mathrm{X}_{\mathrm{S}}\right)$ are assigned to CLASS 1; decay coefficients, $\mathrm{N}$ contents of biomass, maximum specific growth rates and reduction factors are assigned to CLASS 2; all the halfsaturation coefficients are assigned to CLASS 3 apart from the parameters related to AOB denitrification to which the CLASS 4 uncertainty is given. Higher uncertainty is assigned to the parameters related to AOB denitrification in virtue of the fact that these parameters are related to newly-introduced processes, whose modelling is still subject to much higher uncertainties than the parameters related to the other processes originating from the better-established Activated Sludge Model for Nitrogen (AMSN) by Hiatt and Grady [11]. Table 1 summarizes the assignment of uncertainty classes to each ASMG1 parameter.

Table 1: Uncertainty classes for the ASMG1 parameters grouped according to the processes that are described.

\begin{tabular}{|c|c|c|c|c|}
\hline Parameters & Description & $\begin{array}{c}\text { Default value } \\
\text { at } 150 \mathrm{C}\end{array}$ & Unit & CLASS \\
\hline \multicolumn{5}{|c|}{ Aerobic AOB activity } \\
\hline $\mathbf{Y}_{\mathrm{A} 1}$ & growth yield of AOB & 0.18 & $\mathrm{~g} \mathrm{COD}_{\mathrm{BIO}} \cdot \mathrm{g}^{-1} \mathrm{~N}$ & 1 \\
\hline$\mu_{\mathrm{A} 1}$ & maximum specific growth rate of AOB & 0.58 & $\mathrm{~d}^{-1}$ & 2 \\
\hline $\mathbf{K}_{\mathrm{FA}}$ & $\mathrm{NH}_{3}$ half saturation parameter for aerobic AOB activity & 0.004 & g N.m ${ }^{-3}$ & 3 \\
\hline $\mathbf{K}_{\mathbf{O}, \mathbf{A 1}}$ & $\mathrm{O}_{2}$ half-saturation constant for AOB activity & 0.6 & $\mathrm{~g}(-\mathrm{COD}) \cdot \mathrm{m}^{-3}$ & 3 \\
\hline  & $\mathrm{NH}_{3}$ inhibition constant for AOB activity & 1 & g N.m ${ }^{-3}$ & 3 \\
\hline $\mathbf{K}_{\mathrm{I} 9, \mathrm{FNA}}$ & $\mathrm{HNO}_{2}$ inhibition constant for AOB activity & 0.1 & g N.m ${ }^{-3}$ & 3 \\
\hline $\mathbf{b}_{\mathrm{A} 1}$ & decay coefficient of AOB & 0.028 & $\mathrm{~d}^{-1}$ & 2 \\
\hline \multicolumn{5}{|c|}{ NOB activity } \\
\hline$\overline{\mathbf{Y}_{\mathrm{A} 2}}$ & growth yield of NOB & 0.06 & $\mathrm{~g} \mathrm{COD}_{\mathrm{BIO}} \cdot \mathrm{g}^{-1} \mathrm{~N}$ & 1 \\
\hline$\mu_{\mathrm{A} 2}$ & maximum specific growth rate of NOB & 0.68 & $\mathrm{~d}^{-1}$ & 2 \\
\hline $\mathbf{K}_{\mathbf{O}, \mathrm{A} 2}$ & $\mathrm{O}_{2}$ half-saturation constant for NOB activity & 1.2 & $\mathrm{~g}(-\mathrm{COD}) \cdot \mathrm{m}^{-3}$ & 3 \\
\hline
\end{tabular}




\begin{tabular}{|c|c|c|c|c|}
\hline $\mathbf{K}_{\mathrm{I10,FA}}$ & $\mathrm{NH}_{3}$ inhibition constant for NOB activity & 0.5 & g N.m $\mathrm{m}^{-3}$ & 3 \\
\hline $\mathbf{K}_{\mathrm{I10,FNA}}$ & $\mathrm{HNO}_{2}$ inhibition constant for NOB activity & 0.1 & g N.m $\mathrm{m}^{-3}$ & 3 \\
\hline $\mathbf{K}_{\text {FNA }}$ & $\mathrm{HNO}_{2}$ half saturation parameter for NOB activity & $10^{-6}$ & g N.m ${ }^{-3}$ & 3 \\
\hline $\mathbf{b}_{\mathrm{A} 2}$ & decay coefficient of NOB & 0.028 & $\mathrm{~d}^{-1}$ & 2 \\
\hline \multicolumn{5}{|c|}{ Aerobic HB activity } \\
\hline $\mathbf{Y}_{\mathbf{H}}$ & growth yield of $\mathrm{HB}$ & 0.6 & $\begin{array}{c}\text { g CODBIO.g } g^{-1} \\
\text { COD }\end{array}$ & 1 \\
\hline$\mu_{H}$ & maximum specific growth rate of $\mathrm{HB}$ & 4.78 & $\mathrm{~d}^{-1}$ & 2 \\
\hline $\mathbf{K}_{\mathrm{S} 1}$ & $\mathrm{~S}_{\mathrm{S}}$ half-saturation coefficient for aerobic HB activity & 15 & g COD.m ${ }^{-3}$ & 3 \\
\hline $\mathbf{K}_{\mathrm{OH} 1}$ & $\mathrm{O}_{2}$ half saturation coefficient for aerobic HB activity & 0.2 & $\mathrm{~g}(-\mathrm{COD}) \cdot \mathrm{m}^{-3}$ & 3 \\
\hline $\mathbf{b}_{\mathrm{H}}$ & decay coefficient of HB & 0.3 & $\mathrm{~d}^{-1}$ & 2 \\
\hline \multicolumn{5}{|c|}{ HB denitrification } \\
\hline $\mathbf{n}_{\mathbf{Y}}$ & anoxic reduction factor for HB yield & 0.9 & {$[-]$} & 1 \\
\hline $\mathrm{K}_{\mathrm{I} 3 \mathrm{NO}}$ & NO inhibition constant of for $\mathrm{HB}$-mediated $\mathrm{NO}_{2}^{-}$reduction & 0.5 & g N.m $\mathrm{m}^{-3}$ & 3 \\
\hline $\mathrm{K}_{\mathrm{I} 4, \mathrm{NO}}$ & NO inhibition constant of for HB-mediated NO reduction & 0.3 & g N.m ${ }^{-3}$ & 3 \\
\hline $\mathbf{K}_{\mathrm{I} 5, \mathrm{NO}}$ & NO inhibition constant of for $\mathrm{HB}$-mediated $\mathrm{N}_{2} \mathrm{O}$ reduction & 0.2 & g N.m ${ }^{-3}$ & 3 \\
\hline $\mathbf{K}_{\mathrm{N} 2 \mathrm{O}}$ & $\mathrm{N}_{2} \mathrm{O}$ half-saturation for HB-mediated $\mathrm{N}_{2} \mathrm{O}$ reduction & 0.02 & g N.m ${ }^{-3}$ & 3 \\
\hline $\mathbf{K}_{\mathrm{NO}}$ & NO half-saturation for HB-mediated NO reduction & 0.04 & g N.m ${ }^{-3}$ & 3 \\
\hline $\mathbf{K}_{\mathrm{NO} 2}$ & $\mathrm{NO}_{2}^{-}$half-saturation for $\mathrm{HB}$-mediated $\mathrm{NO}_{2}^{-}$reduction & 0.3 & g N.m ${ }^{-3}$ & 3 \\
\hline $\mathbf{K}_{\mathrm{NO} 3}$ & $\mathrm{NO}_{3}{ }^{-}$half-saturation for $\mathrm{HB}$-mediated $\mathrm{NO}_{3}{ }^{-}$reduction & 1.5 & g N.m ${ }^{-3}$ & 3 \\
\hline $\mathbf{K}_{\mathrm{S} 2}$ & $\mathrm{~S}_{\mathrm{S}}$ half-saturation coefficient for $\mathrm{HB}$-mediated $\mathrm{NO}_{3}{ }^{-}$reduction & 20 & g COD.m ${ }^{-3}$ & 3 \\
\hline $\mathbf{K}_{\mathrm{S} 3}$ & $\mathrm{~S}_{\mathrm{S}}$ half-saturation coefficient for $\mathrm{HB}$-mediated $\mathrm{NO}_{2}^{-}$reduction & 20 & g COD. $\mathrm{m}^{-3}$ & 3 \\
\hline $\mathbf{K}_{\mathrm{S} 4}$ & $\mathrm{~S}_{\mathrm{S}}$ half-saturation coefficient for HB-mediated NO reduction & 20 & g COD.m ${ }^{-3}$ & 3 \\
\hline $\mathbf{K}_{\mathrm{S} 5}$ & $\mathrm{~S}_{\mathrm{S}}$ half-saturation coefficient for $\mathrm{HB}$-mediated $\mathrm{N}_{2} \mathrm{O}$ reduction & 30 & g COD. $\mathrm{m}^{-3}$ & 3 \\
\hline $\mathbf{n}_{\mathrm{g} 2}$ & reduction factor for $\mathrm{HB}$ anoxic growth on $\mathrm{NO}_{3}{ }^{-}$ & 0.3 & {$[-]$} & 2 \\
\hline $\mathbf{n}_{\mathrm{g} 3}$ & reduction factor for $\mathrm{HB}$ anoxic growth on $\mathrm{NO}_{2}{ }^{-}$ & 0.3 & {$[-]$} & 2 \\
\hline $\mathbf{n}_{\mathrm{g} 4}$ & reduction factor for HB anoxic growth on NO & 0.6 & {$[-]$} & 2 \\
\hline $\mathbf{n}_{\mathrm{g} 5}$ & reduction factor for $\mathrm{HB}$ anoxic growth on $\mathrm{N}_{2} \mathrm{O}$ & 0.8 & {$[-]$} & 2 \\
\hline $\mathbf{K}_{\mathrm{OH} 2}$ & $\mathrm{O}_{2}$ inhibition coefficient for $\mathrm{HB}$-mediated $\mathrm{NO}_{3}{ }^{-}$reduction & 0.2 & $\mathrm{~g}(-\mathrm{COD}) \cdot \mathrm{m}^{-3}$ & 3 \\
\hline $\mathbf{K}_{\mathrm{OH} 3}$ & $\mathrm{O}_{2}$ inhibition coefficient for $\mathrm{HB}$-mediated $\mathrm{NO}_{2}^{-}$reduction & 0.2 & $\mathrm{~g}(-\mathrm{COD}) \cdot \mathrm{m}^{-3}$ & 3 \\
\hline $\mathbf{K}_{\mathrm{OH} 4}$ & $\mathrm{O}_{2}$ inhibition coefficient for HB-mediated NO reduction & 0.2 & $\mathrm{~g}(-\mathrm{COD}) \cdot \mathrm{m}^{-3}$ & 3 \\
\hline $\mathbf{K}_{\mathrm{OH} 5}$ & $\mathrm{O}_{2}$ inhibition coefficient for HB-mediated $\mathrm{N} 2 \mathrm{O}$ reduction & 0.2 & $\mathrm{~g}(-\mathrm{COD}) \cdot \mathrm{m}^{-3}$ & 3 \\
\hline \multicolumn{5}{|c|}{ Hydrolysis of particulate organics } \\
\hline $\mathbf{k}_{\mathbf{h}}$ & maximum specific hydrolysis rate & 2.89 & $\begin{array}{c}\text { g COD.g }^{-1} \\
\text { COD }_{\text {BIO }}\end{array}$ & 2 \\
\hline $\mathbf{n}_{\mathbf{h}}$ & reduction factor for hydrolysis & 0.8 & {$[-]$} & 2 \\
\hline $\mathrm{K}_{\mathrm{OH}}$ & $\mathrm{O}_{2}$ half-saturation coefficient for hydrolysis & 0.2 & $\mathrm{~g}(-\mathrm{COD}) \cdot \mathrm{m}^{-3}$ & 3 \\
\hline $\mathbf{K}_{\mathbf{X}}$ & Half-saturation coefficient for hydrolysis of $\mathrm{X}_{\mathrm{S}}$ & 0.1 & g COD.m ${ }^{-3}$ & 1 \\
\hline \multicolumn{5}{|c|}{ Ammonification } \\
\hline $\mathbf{k}_{\mathbf{a}}$ & Rate constant for ammonification & 0.07 & $\begin{array}{c}\mathrm{m}^{3} \cdot \mathrm{g}^{-1} \\
\operatorname{COD}_{\text {BIO }} \cdot \mathrm{d}^{-1}\end{array}$ & 3 \\
\hline \multicolumn{5}{|c|}{ AOB denitrification } \\
\hline $\mathbf{K}_{\mathrm{SNO}, \mathrm{AOB}}$ & NO half saturation coefficient for AOB-mediated NO reduction & 1 & g N.m ${ }^{-3}$ & 4 \\
\hline K $_{\text {SO,AOBden1 }}$ & $\mathrm{O}_{2}$ half saturation coefficient for AOB-mediated NO2- reduction & 11.4 & $\mathrm{~g}(-\mathrm{COD}) \cdot \mathrm{m}^{-3}$ & 4 \\
\hline $\mathrm{K}_{\mathrm{IO}, \mathrm{AOBden} 1}$ & $\mathrm{O}_{2}$ inhibition coefficient for AOB-mediated NO2- reduction & 0.0351 & $\mathrm{~g}(-\mathrm{COD}) \cdot \mathrm{m}^{-3}$ & 4 \\
\hline $\mathbf{K}_{\text {SO,AOBden2 }}$ & $\mathrm{O}_{2}$ half saturation coefficient for AOB-mediated NO reduction & 11.4 & $\mathrm{~g}(-\mathrm{COD}) \cdot \mathrm{m}^{-3}$ & 4 \\
\hline $\mathrm{K}_{\mathrm{IO}, \mathrm{AOBden} 2}$ & $\mathrm{O}_{2}$ inhibition coefficient for AOB-mediated NO reduction & 0.0351 & $\mathrm{~g}(-\mathrm{COD}) \cdot \mathrm{m}^{-3}$ & 4 \\
\hline $\mathbf{n}_{\mathrm{AOB}}$ & reduction factor for $\mathrm{AOB}$ growth on $\mathrm{NO}_{2}{ }^{-}$and on $\mathrm{NO}$ & 0.5 & {$[-]$} & 4 \\
\hline $\mathbf{K}_{\text {FNA,AOB }}$ & $\mathrm{HNO}_{2}$ half saturation coefficient for AOB-mediated NO2- reduction & $6 \cdot 10^{-4}$ & g N.m $\mathrm{m}^{-3}$ & 4 \\
\hline $\mathbf{K}_{\mathrm{FA}, \mathrm{AOB}}$ & $\mathrm{NH}_{3}$ half saturation coefficient for AOB-mediated $\mathrm{NO}_{2}{ }^{-}$and $\mathrm{NO}$ reduction & 0.0027 & g N.m ${ }^{-3}$ & 4 \\
\hline \multicolumn{5}{|c|}{ AnAOB activity } \\
\hline
\end{tabular}




\begin{tabular}{|c|c|c|c|c|}
\hline$\overline{\mathbf{Y}_{\text {AnAOB }}}$ & growth yield of AnAOB & 0.16 & $\mathrm{~g} \mathrm{COD}_{\mathrm{BIO}} \cdot \mathrm{g}^{-1} \mathrm{~N}$ & 1 \\
\hline$\mu_{\mathrm{AnAOB}}$ & maximum specific growth rate of $\mathrm{AnAOB}$ & 0.0173 & $\mathrm{~d}^{-1}$ & 2 \\
\hline $\mathbf{K}_{\mathrm{NH} 3, \mathrm{AnAOB}}$ & NH3 half saturation coefficient for AnAOB activity & 0.0012 & g N.m ${ }^{-3}$ & 3 \\
\hline $\mathrm{K}_{\mathrm{HNO} \text {,AnAOB }}$ & HNO2 half saturation coefficient for AnAOB activity & $2.81 \cdot 10^{-6}$ & g N.m ${ }^{-3}$ & 3 \\
\hline $\mathrm{K}_{\mathrm{O} 2 \text {,AnAOB }}$ & O2 inhibition coefficient for AnAOB activity & 0.01 & $\mathrm{~g}(-\mathrm{COD}) \cdot \mathrm{m}-3$ & 3 \\
\hline $\mathbf{b}_{\mathrm{AnAOB}}$ & decay coefficient of AnAOB & $6.19 \cdot 10^{-4}$ & $\mathrm{~d}-1$ & 2 \\
\hline \multicolumn{5}{|c|}{ Other parameters } \\
\hline $\mathbf{f}_{\mathrm{P}}$ & fraction of $X_{P}$ generated from biomass decay & 0.08 & $\begin{array}{c}\mathrm{g} \mathrm{COD}_{\mathrm{XP}} \cdot \mathrm{g}^{-1} \\
\mathrm{COD}_{\text {BIO }}\end{array}$ & 3 \\
\hline $\mathbf{i}_{\mathrm{XB}}$ & $\mathrm{N}$ content in biomass & 0.086 & g N.g ${ }^{-1}(\mathrm{COD})$ & 2 \\
\hline $\mathbf{i}_{\mathrm{XP}}$ & $\mathrm{N}$ content in $\mathrm{X}_{\mathrm{P}}$ & 0.06 & 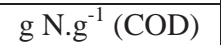 & 2 \\
\hline
\end{tabular}

\section{Monte Carlo and Morris screening samplings}

For the LHS, the number of samples equal to 250 is chosen and no correlation between the parameters was considered. For the Morris sampling, the number of levels $(p)$ in which the parameter space is split up was 8 and the number of points in the parameter space at which the elementary effects are to be calculated was decided to be 15 . Given that the number of uncertain parameters is 61 , a number of samples equal to 930 resulted for the Morris Screening analysis.

Figure 3 summarizes the steps adopted for the sensitivity analyses perturbing model parameters.

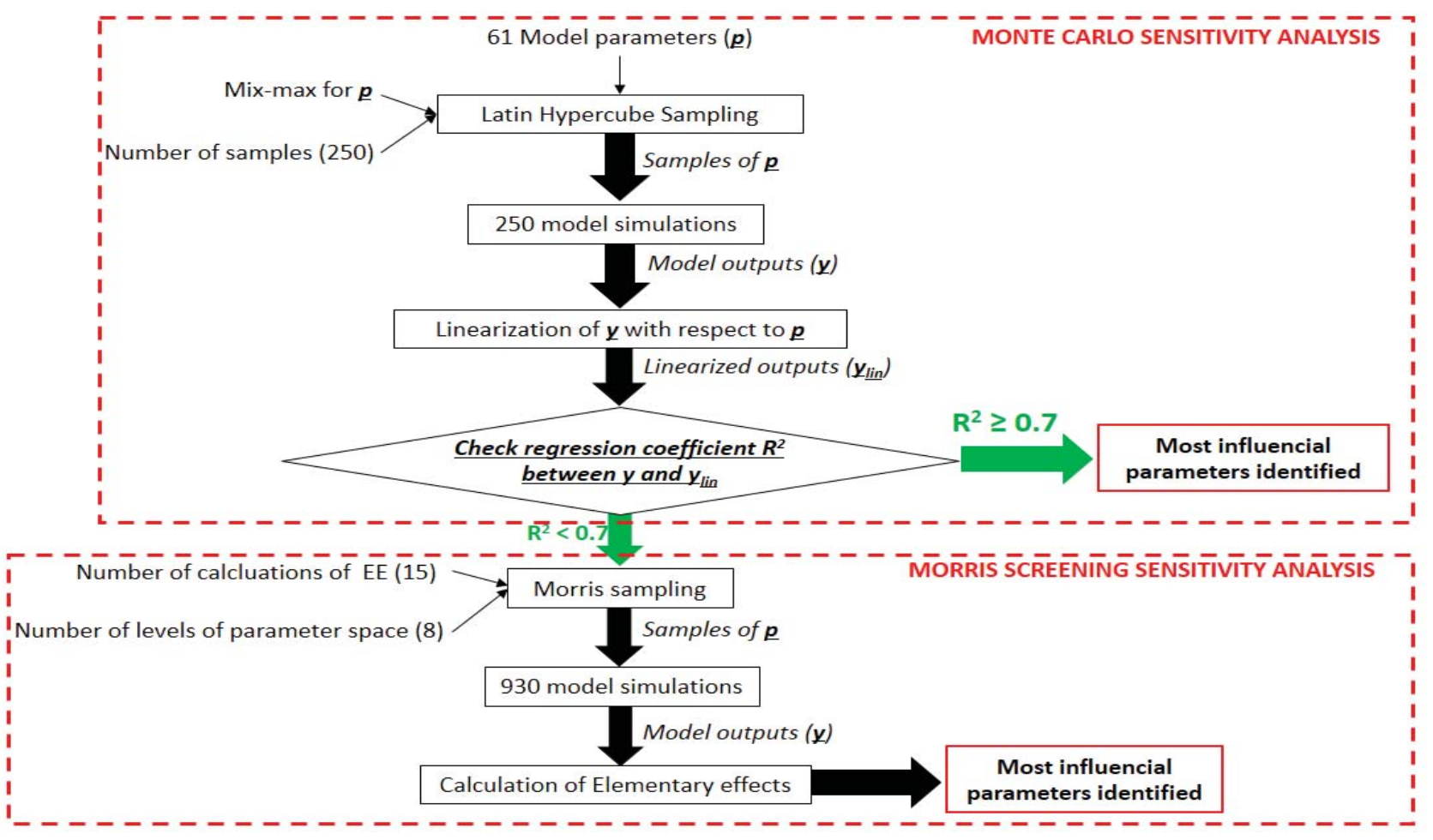

Figure 3: Stepwise procedure adopted to perform the sensitivity analyses by perturbing model parameters. 


\subsection{Sensitivity analyses simulations performed}

For both the sensitivity analysis investigating the effect of operating conditions and the one investigating the effect of parameter uncertainties, steady-state simulations were performed by controlling the concentration of total suspended solids (TSSs) in the last aerobic tank (AER3) at a set point of $4000 \mathrm{mg}$ (TSS). $\mathrm{L}^{-1}$ by manipulating the wastage flow rate, carried out directly from AER3 to the thickener in the side stream. This TSS control is implemented with the aim of keeping the plant Sludge Retention Time (SRT) within a limited design range. Furthermore, in order to check the effect of operating temperature on the biological mechanisms determining the TN removal efficiency and the $\mathrm{N}_{2} \mathrm{O}$ emissions, additional sets of simulations were performed by setting the operating temperature in the biological system not only to $15^{\circ} \mathrm{C}$, but also to $10^{\circ} \mathrm{C}$ and $20^{\circ} \mathrm{C}$. Thus mechanisms determining $\mathrm{N}_{2} \mathrm{O}$ emissions, $\eta_{\mathrm{TN}}$ and oxygen consumptions in typical winter, autumn/spring and summer are investigated. For the sensitivity analysis investigating the effect of parameter uncertainties on the model predictions (i.e. Monte Carlo and Morris screening analyses), also the oxygen concentration in the three aerobic tanks is controlled at four key set points, identified according to the function describing the oxygen influence on the AOB denitrification process rate, depicted in Figure 4. The reason for this is that $\mathrm{AOB}$ have been extensively reported to be the most important contributors to the total $\mathrm{N}_{2} \mathrm{O}$ emitted $[4,6,22-24]$. By plotting the Haldane function describing the direct correlation between AOB denitrification and oxygen in Figure 4, it appears clearly that small variations of the oxygen concentration can make a huge difference on the rate of AOB denitrification and, consequently, on the $\mathrm{N}_{2} \mathrm{O}$ emissions. The four oxygen set points were chosen as follows:

- $\quad 0.3 \mathrm{mg}(-\mathrm{COD}) . \mathrm{L}^{-1}$, where oxygen has an enhancing effect,

- $\quad 0.65 \mathrm{mg}(-\mathrm{COD}) \cdot \mathrm{L}^{-1}$, where oxygen is maximizing the Haldane function,

- $1 \mathrm{mg}(-\mathrm{COD}) \cdot \mathrm{L}^{-1}$, where oxygen has a moderately inhibiting effect, and

- $2 \mathrm{mg}$ (-COD). $\mathrm{L}^{-1}$, where oxygen has a strong inhibiting effect. 


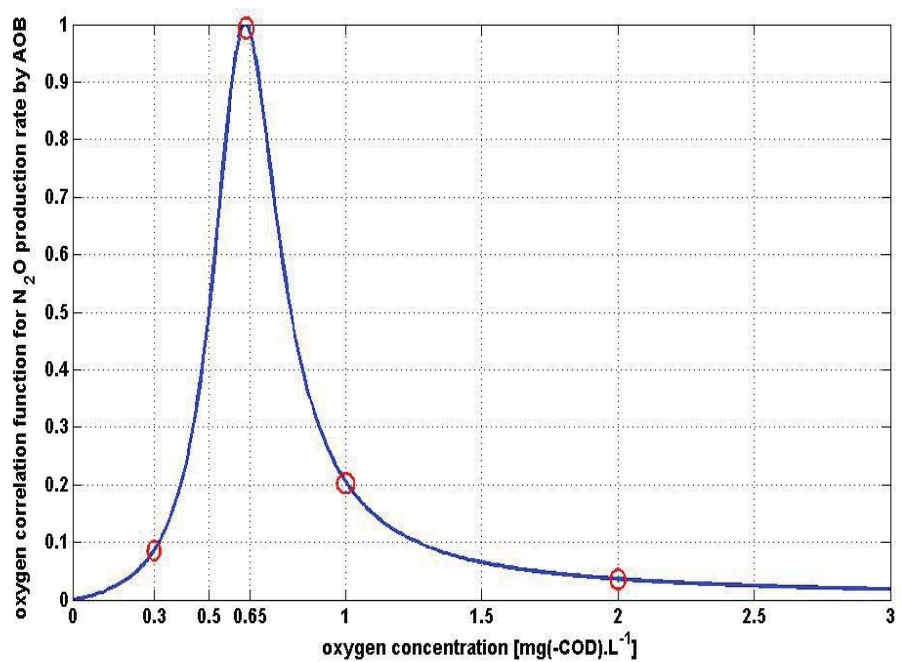

Figure 4: Oxygen inhibition function for the $\mathrm{N}_{2} \mathrm{O}$ production rate by AOB.

Figure 5 shows the configuration of the BSM2N used during the steady-state simulations for the SA investigating the propagation of ASMG1 parameter uncertainties on the predictions. As can be seen, the configuration is implemented with different Proportional Integral (PI) controllers: three oxygen concentration controllers for the three aerated tanks, which manipulate the respective oxygen mass transfer coefficient, and the TSS controller in AER3, which manipulates the wastage flow rate $\left(\mathrm{Q}_{\mathrm{W}}\right)$. The configuration of the BSM2N used during the steady-state simulations for the SA investigating the operating conditions is the same but without the three oxygen controllers. Table 2 summarizes the scenarios for the sensitivity analysis that was performed. 


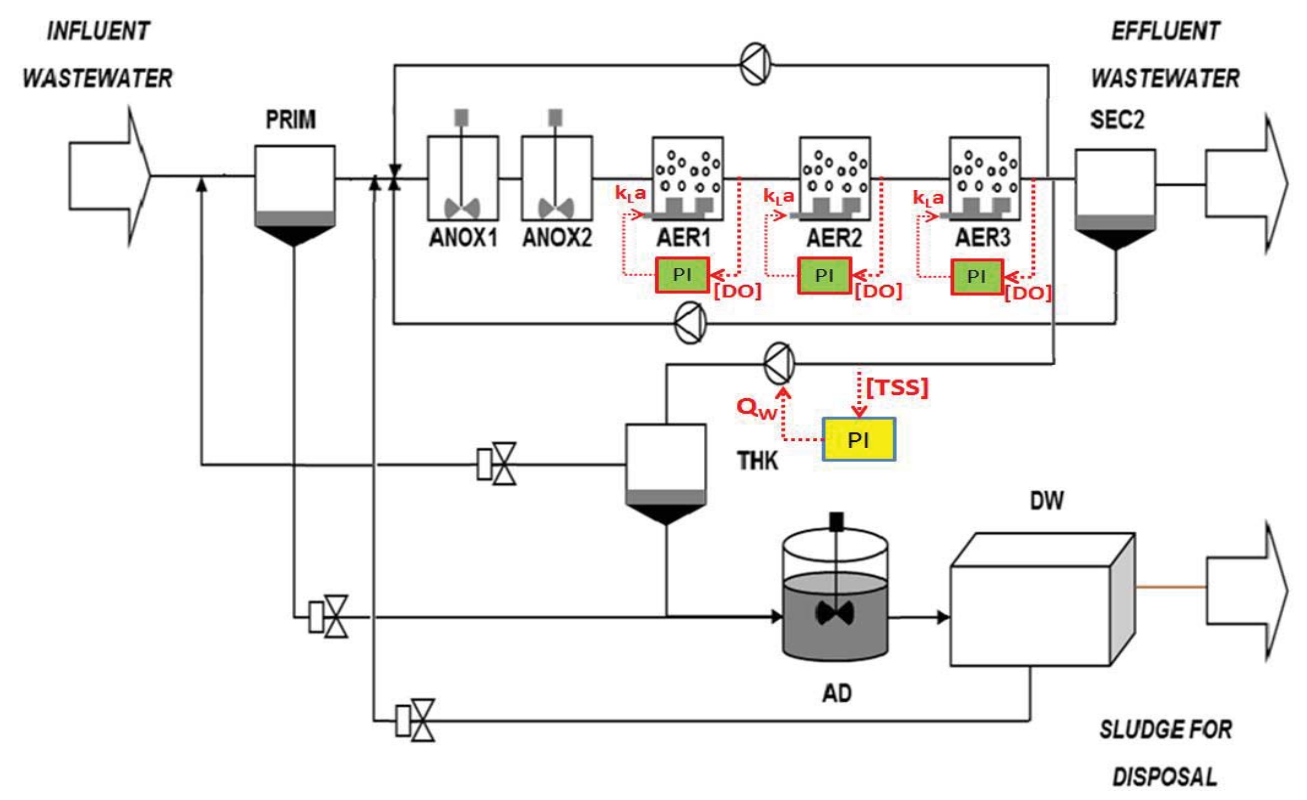

Figure 5: BSM2N used during steady-state simulations for sensitivity analyses investigating ASMG1 parameter uncertainties [8].

Table 2: Scenarios of sensitivity analyses performed.

\begin{tabular}{|c|c|c|}
\hline scenario & SENSITIVITY ANALYSIS & PLANT CONFIGURATION \\
\hline $\mathbf{1}$ & $\begin{array}{c}\text { PERTURBATION OF OPERATING CONDITIONS FOR } \\
\text { INPUT-OUTPUT MAPPING } \\
\text { (FULL-FACTORIAL DESIGN) }\end{array}$ & TSS CONTROL \\
\hline $\mathbf{2 a}$ & $\begin{array}{c}\text { PERTURBATION OF MODEL PARAMETERS } \\
\text { THROUGH MONTE CARLO REGRESSION } \\
\text { PROCEDURE }\end{array}$ & $\begin{array}{c}\text { OXYGEN AND TSS } \\
\text { CONTROL }\end{array}$ \\
\hline $\mathbf{2 b}$ & $\begin{array}{c}\text { PERTURBATION OF MODEL PARAMETERS } \\
\text { THROUGH MORRIS SCREENING PROCEDURE }\end{array}$ & $\begin{array}{c}\text { OXYGEN AND TSS } \\
\text { CONTROL }\end{array}$ \\
\hline
\end{tabular}




\section{Results and Discussion}

\subsection{The total nitrogen removal efficiency}

Sensitivity analysis perturbing the operating conditions: Input-Output mapping

The TN removal efficiency resulting from the sensitivity analysis regarding the operating conditions is plotted against the influent oxygen-to-total-Kjeldahl-nitrogen ratio (RO) in Figure 6. RO is a parameter indicating the amount of oxygen supplied versus the amount of Total Kjeldahl Nitrogen (TKN) in the influent to the activated sludge unit, calculated according to Eqn. (12). This ratio was also used by Vangsgaard et al. [21] and typically indicates the aeration regime of the treatment plant.

$$
R O=\frac{\sum_{i=1}^{n} k_{L} a_{A E R, i} \cdot V_{A E R, i} \cdot\left(S_{O 2, S a t, A E R, i}-S_{O 2, A E R, i}\right)}{Q_{\text {inAS }} \cdot\left(S_{N D, \text { inAS }}+X_{N D, \text { inAS }}+S_{N H, \text { in AS }}\right)}
$$

In Eqn. (12):

- $k_{L} a_{A E R, i}$ is the oxygen mass transfer coefficient of the aerated tank $i$,

- $V_{A E R, i}$ is the volume of the aerobic tank $i$, corresponding to $3000 \mathrm{~m}^{3}$,

- $S_{O 2, S A T, i}$ is the oxygen saturation concentration of the aerobic tank $i$,

- $S_{O 2, A E R, i}$ is the oxygen concentration in the aerobic tank $i$,

- $Q_{\text {inAs }}$ is the inlet flow rate fed to the biological zone,

- $S_{N D \text {,inAS }}$ is the inlet soluble organic nitrogen fed to the biological zone,

- $X_{N D, i n A S}$ is the inlet particulate organic nitrogen fed to the biological zone,

- $S_{N H, \text { inAS }}$ is the inlet ammonium nitrogen fed to the biological zone.

Eqn. (12) assumes that each aerobic tank is characterized by a unique value of $\mathrm{k}_{\mathrm{L}} \mathrm{a}$.

As can be noted from Figure 6, independently from the operating temperature the TN removal efficiency increases with the increase of RO until a maximal value, after which it decreases with a rather scattered behaviour according to the amount of $\mathrm{NH}_{4}{ }^{+}$in the influent. In particular, as the influent $\mathrm{NH}_{4}{ }^{+}$increases, the decrease of $\eta_{\mathrm{TN}}$ gets steeper. The trend found suggests that for all the three temperatures there is a value for 
$\mathrm{RO}\left(\mathrm{RO}_{\operatorname{maxTNrem}}\right)$ at which the analysed output variable is maximized. In particular, for values of RO lower than $\mathrm{RO}_{\operatorname{maxTNrem}}$ the NOB activity is at zero whereas $\mathrm{AOB}$ activity gradually increases as RO increases (see Figures A3a and A3b in the Supplementary Information (SI)). On the basis of the removal efficiency of nitrogen oxides (namely, the sum of $\mathrm{NO}_{3}{ }^{-}$and $\mathrm{NO}_{2}{ }^{-}$) in the anoxic zone (see Figure A3c in SI), for values of RO lower than $\mathrm{RO}_{\text {maxTNrem }} \mathrm{HB}$ denitrification works at its maximal efficiency since oxygen is not found in an inhibiting concentration. Furthermore, considering that influent $\mathrm{NH}_{4}{ }^{+}$is converted into $\mathrm{NO}_{2}{ }^{-}$and not into $\mathrm{NO}_{3}{ }^{-}$, the $\mathrm{NO}_{2}{ }^{-}$reduction route for $\mathrm{HB}$ denitrification is followed rather than the $\mathrm{NO}_{3}{ }^{-}$reduction one, which requires a smaller amount of organic biodegradable carbon [25]. When $\mathrm{RO}$ is higher than $\mathrm{RO}_{\operatorname{maxTNrem}}$, NOB start growing. Due to the fact that HB denitrification requires more organic biodegradable carbon for the $\mathrm{NO}_{3}{ }^{-}$reduction route, the TN removal efficiency starts decreasing. As the amount of oxygen supplied per unit of TKN fed grows further, HB denitrification is more and more inhibited by the oxygen carried into the anoxic zone through the internal recycle. As a result of $\mathrm{HB}$ denitrification inhibition, more organic carbon is oxidized by consuming oxygen. This leads to higher HB activity (see Figure A3d in SI). The extra amount of oxygen consumed by HB for the oxidation of organic carbon is no longer available for AOB and NOB, whose activity rates decreases.

As can be additionally noted, the value of $\mathrm{RO}_{\operatorname{maxTNrem}}$ sensibly increases as the operating temperature increases. This means that, as temperature increases, for the same amount of TKN fed in the system, more oxygen is needed to maximize the TN removal efficiency. This is ascribed to the higher amount of oxygen consumed via endogenous respiration of biomass.

Finally, it is here important to point out that the results are achieved for a fixed design of the biological zone, where an anoxic zone of $3000 \mathrm{~m}^{3}$ precedes an aerobic zone of $9000 \mathrm{~m}^{3}$. When the relative position of these zones switches (i.e. in a post-denitrification system), it is expected that, being the volume the same, HB denitrification occurs at a lower rate due to lower availability of organic carbon and higher oxygen inhibition and that $\eta_{\mathrm{TN}}$ drops down faster after $\mathrm{RO}_{\text {maxTNrem}}$. Furthermore, keeping the total tank volume the same (i.e. in a pre-denitrification system), the larger the anoxic volume, the higher would be the TN removal efficiency and the less steep would be the drop after $\mathrm{RO}_{\operatorname{maxTN} r e m}$. 


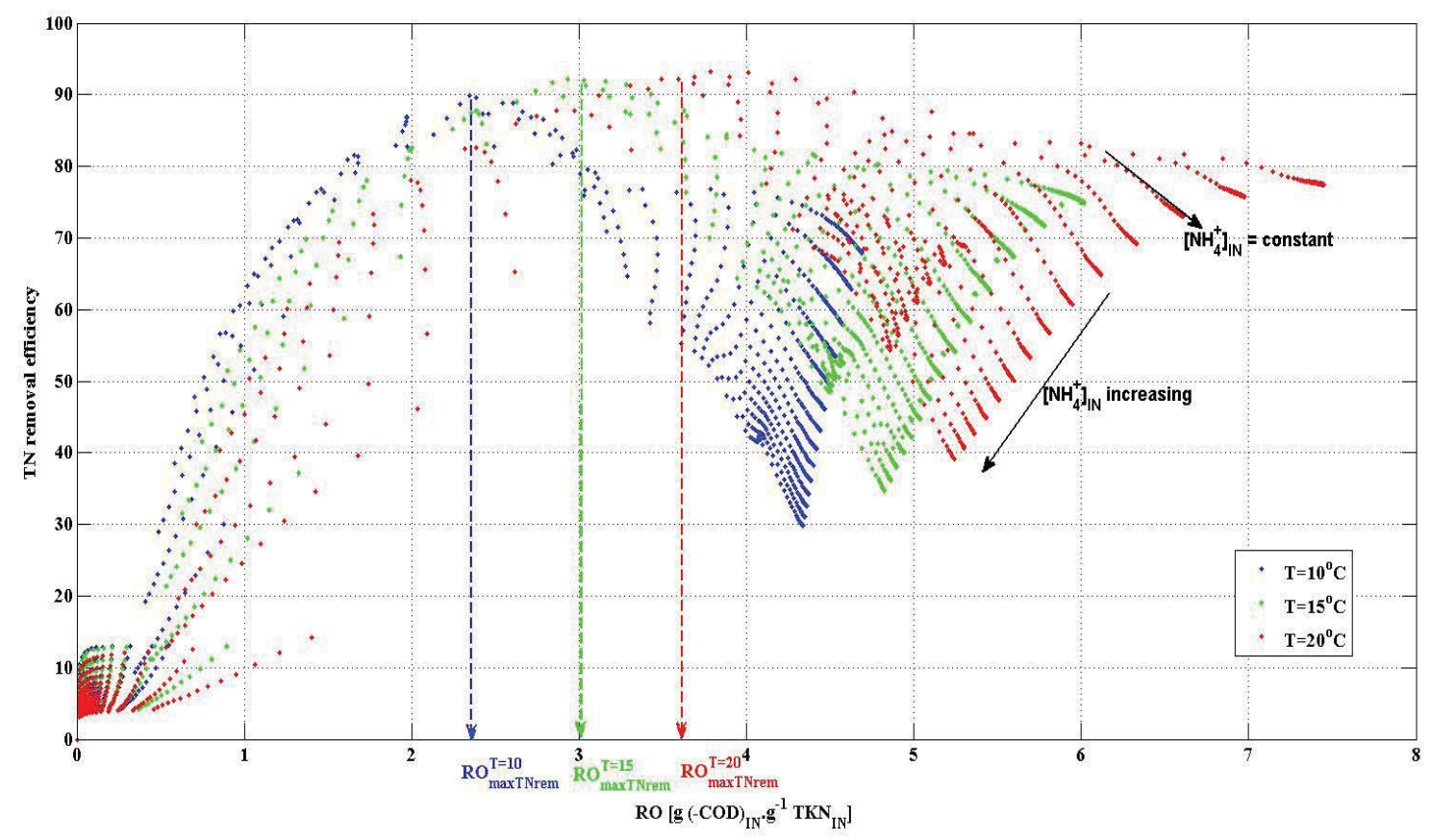

Figure 6: Mapping of TN removal efficiencies as a function of influent oxygen-to-total-Kjeldahl-nitrogen ratio (RO) at temperatures of $10^{\circ} \mathrm{C}, 15^{\circ} \mathrm{C}$ and $20^{\circ} \mathrm{C}$.

\section{Sensitivity analysis perturbing model parameters}

The results of the sensitivity analysis investigating the impact of the parameter uncertainties on the model predictions are here considered. Table 3 shows a summary of the uncertainties of the TN removal efficiency. The sensitivities of the output variable analysed at these operating conditions with respect to the ASMG1 parameters, obtained according to the Monte Carlo procedure, are presented in Table 4. ASMG1 parameters having a standardized regression coefficient $\left(\beta_{i}\right)$ value equal or higher than 0.1 , are considered to have a significant impact on $\eta_{\mathrm{TN}}$. The sensitivity of the outputs was also analysed according to the MS procedure and the results were similar.

As can be noted from the ratio between standard deviation and mean value at all the operating conditions presented in Table 3, the propagation of parameter uncertainties on the predicted TN removal efficiency is low. $\eta_{\mathrm{TN}}$ increases as the temperature increases, since all the processes are generally sped up by temperature. 
On the other side, as oxygen increases, the removal of $\mathrm{TN}$ decreases, except for the case of winter temperatures where a slight increase of oxygen concentration from 0.3 to $0.65 \mathrm{mg}$ (-COD). $\mathrm{L}^{-1}$ results in an improvement of the removal efficiency.

By looking at Table 4, the main processes found to be affecting the TN removal efficiency are: (a) aerobic AOB activity, (b) NOB activity, (c) HB denitrification, and (d) anoxic hydrolysis of entrapped organics $\left(\mathrm{X}_{\mathrm{S}}\right)$. In particular, the aerobic AOB activity has a positive effect, since it is the only process which converts the influent ammonium into a form of nitrogen which can be subsequently reduced into nitrogen gas. NOB activity has a negative effect, since it forces $\mathrm{HB}$ denitrification to work according to the $\mathrm{NO}_{3}{ }^{-}$reduction route. HB denitrification has a positive effect, since it improves the reduction of nitrogen oxides produced by nitrifying biomass into nitrogen gases. Similarly, the anoxic hydrolysis of entrapped organics has an enhancing effect on $\eta_{\mathrm{TN}}$, since it increases the availability of readily biodegradable organic carbon to be used as electron donor during the nitrogen oxide reduction by HB.

As can be further observed, the relevance of the rates of these processes varies in function of operating oxygen concentrations and temperatures. In particular, for the DO concentration equal to $0.3 \mathrm{mg}$ (-COD). $\mathrm{L}^{-1}$ at winter temperatures the parameters describing the rate of $\mathrm{AOB}$ activity are the most influencing ones whereas at other temperatures the parameters describing the rate of NOB activity emerge as the most influencing. This indicates that AOB activity is more limited by oxygen at lower temperatures. On the contrary, at higher temperatures NOB activity is more determining the TN removal efficiency. By looking at the parameters that are most affecting $\eta_{T N}$ at other oxygen concentration set points, it can be noted that, independently from the temperature, the most influencing processes switch from autotrophic activity to anoxic hydrolysis of entrapped organics $\left(\mathrm{X}_{\mathrm{S}}\right)$ and HB denitrification. It is in this case evident that an increase of oxygen concentration in the aerobic zone enhances NOB activity while gradually limiting the anoxic hydrolysis of particulate organic carbon and heterotrophic denitrification via inhibition. 
Table 3: Mean $(\mu)$, standard deviation $(\sigma)$ and ratio between them $(\sigma / \mu)$ for TN removal efficiency at oxygen concentrations in the aerobic zone of $0.3,0.65,1$ and $2 \mathrm{mg}(-\mathrm{COD}) \cdot \mathrm{L}^{-1}$ and at temperatures of $10^{\circ} \mathrm{C}, 15^{\circ} \mathrm{C}$ and $20^{\circ} \mathrm{C}$.

\begin{tabular}{|c|c|c|c|c|c|c|}
\hline & & & & $\overline{D O}[\mathrm{~m}$ & D)..$\left.^{-1}\right]$ & \\
\hline & & & 0.3 & 0.65 & 1 & 2 \\
\hline & & $\boldsymbol{\mu}$ & 57.34 & 61.83 & 59.01 & 55.84 \\
\hline & $\mathrm{T}=10^{\circ} \mathrm{C}$ & $\sigma$ & 31.09 & 7.07 & 5 & 4.63 \\
\hline & & $\sigma / \mu$ & 0.54 & 0.11 & 0.08 & 0.08 \\
\hline & & $\mu$ & 76.85 & 68.79 & 66.2 & 63.56 \\
\hline$\eta_{\text {TN }}$ & $\mathrm{T}=15^{\circ} \mathrm{C}$ & $\sigma$ & 10.86 & 6.03 & 4.81 & 4.76 \\
\hline & & $\sigma / \mu$ & 0.14 & 0.09 & 0.07 & 0.08 \\
\hline & & $\mu$ & 82.08 & 73.98 & 71.7 & 69.77 \\
\hline & $\mathrm{T}=20^{\circ} \mathrm{C}$ & $\sigma$ & 8.59 & 5.02 & 4.23 & 4.2 \\
\hline & & $\sigma / \mu$ & 0.10 & 0.7 & 0.06 & 0.06 \\
\hline
\end{tabular}

Table 4: Sensitivity analysis results with regard to the ASMG1 parameters for TN removal efficiency at oxygen concentrations in the aerobic zone of $0.3,0.65,1$ and $2 \mathrm{mg}(-\mathrm{COD}) \cdot \mathrm{L}^{-1}$ and at temperatures of $10^{\circ} \mathrm{C}$, $15^{\circ} \mathrm{C}$ and $20^{\circ} \mathrm{C}$. Parameters are reported in a decreasing order of importance. The effect of the parameter on $\eta_{\mathrm{TN}}$ is given by the sign within the brackets.

\begin{tabular}{|c|c|c|c|c|c|}
\hline & \multicolumn{4}{|c|}{ DO [mg (-COD). $\left.\mathrm{L}^{-1}\right]$} \\
\hline & & 0.3 & 0.65 & 1 & 2 \\
\hline \multirow{2}{*}{$\eta_{\mathrm{TN}}$} & $\mathrm{T}=10^{\circ} \mathrm{C}$ & $\begin{array}{c}\mathrm{K}_{\mathrm{OA} 1}(-), \mu_{\mathrm{A} 1} \\
(+), \mathrm{K}_{\mathrm{OA} 2}(+) \\
\mathrm{Y}_{\mathrm{A} 1}(+), \mathrm{Y}_{\mathrm{H}}(-) \\
\quad \mathrm{i}_{\mathrm{XP}}(+)\end{array}$ & $\begin{array}{c}\mathrm{n}_{\mathrm{h}}(+), \mathrm{K}_{\mathrm{OA} 2}(+), \mathrm{n}_{\mathrm{Y}}(-), \\
\mu_{\mathrm{A} 2}(-), \mathrm{Y}_{\mathrm{H}}(-), \mu_{\mathrm{A} 1}(+), \\
\mathrm{K}_{\mathrm{OA} 1}(-), \mathrm{K}_{\mathrm{FNA}, \mathrm{AOB}}(-), \\
\mathrm{K}_{\mathrm{NO} 2}(-), \mathrm{n}_{\mathrm{AOB}}(+), \mathrm{K}_{\mathrm{NO} 3} \\
(-) .\end{array}$ & $\begin{array}{c}\mathrm{n}_{\mathrm{h}}(+), \mathrm{n}_{\mathrm{Y}}(-), \mathrm{Y}_{\mathrm{H}}(-), \mathrm{k}_{\mathrm{h}}(+), \\
\mathrm{K}_{\mathrm{OA} 2}^{(+)}, \mathrm{K}_{\mathrm{NO} 3}(-), \mu_{\mathrm{A} 2}(-), \\
\mathrm{K}_{\mathrm{S} 1}(+), \mathrm{K}_{\mathrm{NO2} 2}(-), \mathrm{K}_{\mathrm{S} 3}(-), \\
\mu_{\mathrm{A} 1}(+), \mathrm{b}_{\mathrm{H}}(+), \mathrm{K}_{\mathrm{OA} 1}(-), \\
\mathrm{n}_{\mathrm{g} 3}(+), \mathrm{i}_{\mathrm{XP}}(+) .\end{array}$ & $\begin{array}{c}\mathrm{n}_{\mathrm{h}}(+), \mathrm{n}_{\mathrm{Y}}(-), \mathrm{Y}_{\mathrm{H}}(-), \\
\mathrm{k}_{\mathrm{h}}(+), \mathrm{b}_{\mathrm{H}}(+), \mathrm{K}_{\mathrm{S} 1}(+), \\
\mathrm{K}_{\mathrm{NO} 3}(-), \mathrm{i}_{\mathrm{XB}}(-), \mathrm{K}_{\mathrm{S} 3} \\
(-), \mathrm{K}_{\mathrm{OA} 1}(-), \mathrm{i}_{\mathrm{XP}}(+), \\
\mathrm{K}_{\mathrm{OH} 1}(+) .\end{array}$ \\
\hline & $\mathrm{T}=15^{\circ} \mathrm{C}$ & $\begin{array}{c}\mathrm{K}_{\mathrm{OA} 2}(+), \mu_{\mathrm{A} 2}(- \\
), \mathrm{b}_{\mathrm{A} 2}(+), \mu_{\mathrm{A} 1} \\
(+), \mathrm{K}_{\mathrm{OA} 1}(-), \mathrm{n}_{\mathrm{h}} \\
(+), \mathrm{K}_{\mathrm{S} 3}(-), \\
\mathrm{K}_{\mathrm{N} 2 \mathrm{O}}(-) .\end{array}$ & $\begin{array}{c}\mathrm{n}_{\mathrm{h}}(+), \mathrm{K}_{\mathrm{OA} 2}(+), \mathrm{n}_{\mathrm{Y}}(-), \\
\mu_{\mathrm{A} 2}(-), \mathrm{Y}_{\mathrm{H}}(-), \mathrm{K}_{\mathrm{NO} O 3}(-), \\
\mathrm{k}_{\mathrm{h}}(+), \mu_{\mathrm{A} 1}(+), \mathrm{K}_{\mathrm{FNA} A \mathrm{AOB}} \\
(-), \mathrm{K}_{\mathrm{OA} 1}(-), \mathrm{K}_{\mathrm{NO} 2(-), \mu_{\mathrm{H}}} \\
(+), \mathrm{i}_{\mathrm{XP}(+)}, \mathrm{n}_{\mathrm{AOB}}(+) .\end{array}$ & $\begin{array}{c}\mathrm{n}_{\mathrm{h}}(+), \mathrm{n}_{\mathrm{Y}}(-), \mathrm{k}_{\mathrm{h}}(+), \mathrm{Y}_{\mathrm{H}}(-), \\
\mathrm{K}_{\mathrm{NO3}}(-), \mathrm{K}_{\mathrm{OA} 2}(+), \mu_{\mathrm{A} 2}(-), \\
\mathrm{i}_{\mathrm{XP}}(+), \mathrm{K}_{\mathrm{S} 1}(+), \mathrm{K}_{33}(-), \mathrm{i}_{\mathrm{XB}} \\
(-), \mathrm{n}_{\mathrm{g} 3}(+), \mathrm{K}_{\mathrm{N} 2 \mathrm{O}}(-), \mathrm{K}_{\mathrm{NO} 2} \\
(-) .\end{array}$ & $\begin{array}{c}\mathrm{n}_{\mathrm{h}}(+), \mathrm{n}_{\mathrm{Y}}(-), \mathrm{Y}_{\mathrm{H}}(-), \\
\mathrm{k}_{\mathrm{h}}(+), \mathrm{K}_{\mathrm{NO} 3}(-), \mathrm{K}_{\mathrm{S} 1} \\
(+), \mathrm{i}_{\mathrm{XB}}(-), \mathrm{i}_{\mathrm{XP}}(+), \\
\mathrm{K}_{\mathrm{OA} 1}(-), \mathrm{K}_{\mathrm{S} 3}(-), \mathrm{K}_{\mathrm{OH} 1} \\
(+), \mathrm{K}_{\mathrm{IANO}}(+) .\end{array}$ \\
\hline
\end{tabular}




\begin{tabular}{|c|c|c|c|c|}
\hline $\mathrm{T}=20^{\circ} \mathrm{C}$ & $\begin{array}{c}\mathrm{K}_{\mathrm{OA} 2}(+), \mu_{\mathrm{A} 2}(- \\
), \mathrm{b}_{\mathrm{A} 2}(+), \mathrm{K}_{\mathrm{OA} 1} \\
(-), \mu_{\mathrm{A} 1}(+), \mathrm{k}_{\mathrm{h}} \\
(+), \mathrm{n}_{\mathrm{h}}(+) .\end{array}$ & $\begin{array}{c}\mathrm{K}_{\mathrm{OA} 2}(+), \mathrm{n}_{\mathrm{h}}(+), \mu_{\mathrm{A} 2}(-), \\
\mathrm{k}_{\mathrm{h}}(+), \mathrm{n}_{\mathrm{Y}}(-), \mathrm{K}_{\mathrm{NO} 3}(-), \\
\mathrm{b}_{\mathrm{A} 2}(+), \mathrm{i}_{\mathrm{XB}}(-), \mathrm{K}_{\mathrm{OA} 1}(-), \\
\mathrm{n}_{\mathrm{AOB}}(+) .\end{array}$ & $\begin{array}{c}\mathrm{n}_{\mathrm{h}}(+), \mathrm{k}_{\mathrm{h}}(+), \mathrm{n}_{\mathrm{Y}}(-), \mathrm{K}_{\mathrm{NO} 3} \\
(-), \mathrm{K}_{\mathrm{OA} 2}(+), \mathrm{i}_{\mathrm{XB}}(-), \mu_{\mathrm{A} 2}(- \\
), \mathrm{K}_{\mathrm{FNA}, \mathrm{AOB}}(-), \mathrm{K}_{\mathrm{OA} 1}(-) \\
\mathrm{n}_{\mathrm{AOB}}(+), \mathrm{b}_{\mathrm{H}}(-), \mu_{\mathrm{H}}(+) .\end{array}$ & $\begin{array}{c}\mathrm{n}_{\mathrm{h}}(+), \mathrm{n}_{\mathrm{Y}}(-), \mathrm{k}_{\mathrm{h}}(+), \\
\mathrm{K}_{\mathrm{N} O 3}(-), \mathrm{i}_{\mathrm{XB}}(-), \mathrm{Y}_{\mathrm{H}}(- \\
), \mathrm{K}_{\mathrm{S} 2}(-), \mu_{\mathrm{H}}(+), \\
\mathrm{K}_{\mathrm{OA} 1}(-), \mathrm{i}_{\mathrm{XP}}(+), \mathrm{n}_{\mathrm{g} 2} \\
(+), \mathrm{K}_{\mathrm{OH} 1}(+), \mathrm{K}_{\mathrm{S} 1}(+), \\
\mathrm{K}_{\mathrm{S} 3}(-) .\end{array}$ \\
\hline
\end{tabular}

\subsection{The nitrous oxide emissions}

Sensitivity analysis perturbing the operating conditions

The investigation of the effect of operating conditions on the $\mathrm{N}_{2} \mathrm{O}$ emissions is performed by analysing the behaviour of the $\mathrm{N}_{2} \mathrm{O}$ emission factors, calculated as ratio between the total amount of $\mathrm{N}_{2} \mathrm{O}$ emitted from the biological tanks and the TKN loaded in the biological unit, with RO (see Figure 7). In order to know the contribution by the different microbial groups on the $\mathrm{N}_{2} \mathrm{O}$ emissions reported, the $\mathrm{N}_{2} \mathrm{O}$ produced by AOB and the net $\mathrm{N}_{2} \mathrm{O}$ produced by $\mathrm{HB}$, per unit of influent $\mathrm{TKN}$, in function of $\mathrm{RO}$ are considered (see Figure A4 in SI). The specific net $\mathrm{N}_{2} \mathrm{O}$ produced by $\mathrm{HB}$ represents the difference, in absolute values, between the actual $\mathrm{N}_{2} \mathrm{O}$ produced by $\mathrm{HB}$, resulting from $\mathrm{NO}$ reduction, and the $\mathrm{N}_{2} \mathrm{O}$ consumed via reduction into dinitrogen $\left(\mathrm{N}_{2}\right)$. If the value of this output is negative, the $\mathrm{N}_{2} \mathrm{O}$ consumed by $\mathrm{HB}$ is higher than the $\mathrm{N}_{2} \mathrm{O}$ produced, meaning that $\mathrm{HB}$ have consumed all the $\mathrm{N}_{2} \mathrm{O}$ produced by themselves and an additional fraction of the $\mathrm{N}_{2} \mathrm{O}$ produced by AOB. In addition to these, the average $\mathrm{NO}_{2}{ }^{-}$in the aerobic zone per unit of influent TKN and the concentration of dissolved oxygen in the three aerobic tanks (AER1, AER2 and AER3), are used to help understanding the $\mathrm{N}_{2} \mathrm{O}$ dynamics (see Figures $\mathrm{A} 5$ and $\mathrm{A} 6$ in SI, respectively).

As can be noted by observing the $\mathrm{N}_{2} \mathrm{O}$ produced by $\mathrm{AOB}$ and $\mathrm{HB}$ and the average $\mathrm{NO}_{2}{ }^{-}$in the aerobic zone per unit of influent TKN, at values of RO where nitrites accumulate due to absence of NOB activity, both $\mathrm{HB}$ and $\mathrm{AOB}$ denitrification contribute to total $\mathrm{N}_{2} \mathrm{O}$ emissions.

As RO increases, NOB activity starts getting enhanced (see Figure A3b in SI) and both $\mathrm{HB}$ and AOB denitrification in Figure A4 decrease due to the consequent lower $\mathrm{NO}_{2}^{-}$availability. As a result, the $\mathrm{N}_{2} \mathrm{O}$ emissions decrease. However, a further increase of RO would trigger grossly AOB denitrification, thus 
increasing the $\mathrm{N}_{2} \mathrm{O}$ emission factor rapidly. The present scenario is achieved at concentrations of dissolved oxygen in the first aerobic tank between 0.5 and $0.7 \mathrm{mg}(-\mathrm{COD}) . \mathrm{L}^{-1}$ (see Figure A6a in SI), which represents the operating condition where the Haldane-function reaches a maximum. In practical terms, this indicates a very high $\mathrm{N}_{2} \mathrm{O}$ production and emission due to accumulation of the nitritation intermediate $\mathrm{NH}_{2} \mathrm{OH}$. Mere measurements of nitrites do therefore not constitute a sufficient indication for high $\mathrm{N}_{2} \mathrm{O}$ emissions, because it can be that part of the nitrite consumed is used by $\mathrm{AOB}$ for the oxidation of $\mathrm{NH}_{2} \mathrm{OH}$ to produce $\mathrm{N}_{2} \mathrm{O}$ and not entirely by NOB.

Under the same operating conditions, as the liquid concentration of $\mathrm{N}_{2} \mathrm{O}$ becomes particularly high, the $\mathrm{N}_{2} \mathrm{O}$ -to- $\mathrm{N}_{2}$ reduction by $\mathrm{HB}$ is enhanced, leading to negative net $\mathrm{N}_{2} \mathrm{O}$ production by $\mathrm{HB}$. AOB denitrification under this condition is faster for higher temperatures, since AOB activity, similarly to other microbial processes, is enhanced by temperature. In virtue of this, the amount of $\mathrm{N}_{2} \mathrm{O}$ generated from AOB denitrification is generally lower for colder temperatures; hence it is observed that at winter temperatures the contribution by HB denitrification is much more comparable to the one by AOB than for the other seasons. In general, $\mathrm{N}_{2} \mathrm{O}$ emissions increase for higher temperatures.

Independently from the temperature, as oxygen concentration increases further, the operating conditions become inhibiting to both $\mathrm{AOB}$ and $\mathrm{HB}$ denitrification, and the $\mathrm{N}_{2} \mathrm{O}$ emissions drop consistently down.

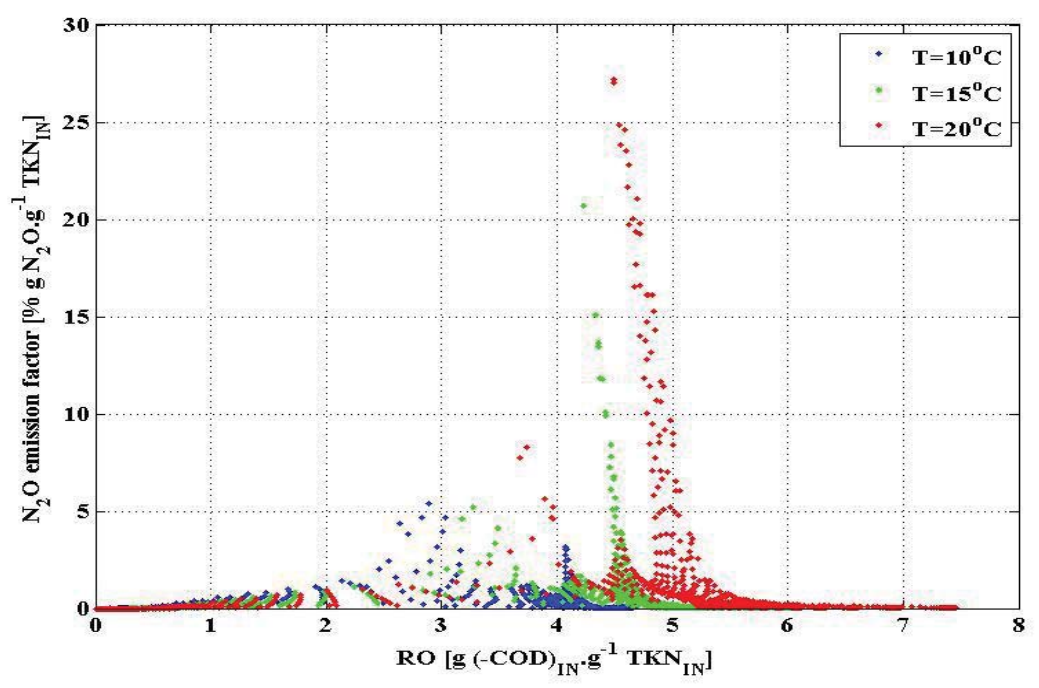

Figure 7: $\mathrm{N}_{2} \mathrm{O}$ emission factors as function of influent oxygen-to-total-Kjeldahl-nitrogen ratio (RO) at temperatures of $10^{\circ} \mathrm{C}, 15^{\circ} \mathrm{C}$ and $20^{\circ} \mathrm{C}$. 
Sensitivity analysis perturbing the model parameters

Given the high uncertainty associated with the parameter values related to the processes describing $\mathrm{N}_{2} \mathrm{O}$ production, the results of the sensitivity analysis investigating propagation of ASMG1 parameter uncertainties on $\mathrm{N}_{2} \mathrm{O}$ emissions are considered. With regard to this, only the results from the Morris screening procedure could be reliably used because finding reliably a sufficiently linear relationship between $\mathrm{N}_{2} \mathrm{O}$ emissions and the ASMG1 parameters during the Monte Carlo procedure was not possible. Among the ASMG1 parameters, those having a mean value of the standardized elementary effect (SEE) equal or larger than 0.01 are considered to have a significant effect on the $\mathrm{N}_{2} \mathrm{O}$ emissions. The fact that the $\mathrm{N}_{2} \mathrm{O}$ emissions could not be linearly regressed with respect to the parameters could have been foreseen from the highly nonlinear behaviour that the $\mathrm{N}_{2} \mathrm{O}$ emission factors have with respect to RO, as clearly depicted in Figure 7.

The ratios between standard deviations and mean values $(\sigma / \mu)$ reported in Table 5 result in values which are significantly higher than unity. For this reason, it can be stated that the propagation of parameter uncertainties to the $\mathrm{N}_{2} \mathrm{O}$ emissions predicted by the model is very strong and significant. This does not allow identifying any general trend of $\mathrm{N}_{2} \mathrm{O}$ emissions as a function of oxygen concentration set point and temperature. Hence, the aforementioned observation according to which $\mathrm{N}_{2} \mathrm{O}$ emissions increase with temperature cannot be taken, for the moment, as reliable before a better identification of the kinetic parameters describing $\mathrm{N}_{2} \mathrm{O}$ dynamics is performed. Nevertheless, the parameters most influencing $\mathrm{N}_{2} \mathrm{O}$ emissions could be identified through the Morris screening procedure. This knowledge allows detecting the changes in the biological mechanisms responsible for $\mathrm{N}_{2} \mathrm{O}$ emissions according to operating oxygen concentration and temperature, which would be used as basis for the development of control strategies aiming at its minimization. The processes by which the $\mathrm{N}_{2} \mathrm{O}$ emissions result most affected are: (a) the last HB denitrification step, during which $\mathrm{N}_{2} \mathrm{O}$ is converted into $\mathrm{N}_{2}$, (b) the first $\mathrm{HB}$ denitrification step, during which $\mathrm{NO}_{3}{ }^{-}$is converted into $\mathrm{NO}_{2}{ }^{-}$, (c) AOB denitrification, and (d) NOB activity. In particular, the rate of the last $\mathrm{HB}$ denitrification step has a negative effect on $\mathrm{N}_{2} \mathrm{O}$ emissions, since it consumes $\mathrm{N}_{2} \mathrm{O}$. Contrarily, the rate of the first $\mathrm{HB}$ denitrification step is revealed to have a positive effect, since it promotes accumulation of $\mathrm{NO}_{2}^{-}$. AOB denitrification obviously affects $\mathrm{N}_{2} \mathrm{O}$ emissions positively, whereas NOB 
activity is found to have a negative effect, since it consumes $\mathrm{NO}_{2}{ }^{-}$in the aerobic zone, thus preventing its conversion into $\mathrm{N}_{2} \mathrm{O}$ by both $\mathrm{AOB}$ and $\mathrm{HB}$.

The results in Table 6 are analysed at different dissolved oxygen set points, leading to the following conclusions:

- at very low DO concentrations (i.e. $0.3 \mathrm{mg}(-\mathrm{COD}) \cdot \mathrm{L}^{-1}$ ), while for winter temperatures the primary dominant process is the last HB denitrification step, at other temperatures NOB activity is the dominant process;

- at DO concentrations equal to 0.65 and $\left.1 \mathrm{mg}(-\mathrm{COD}) \cdot \mathrm{L}^{-1}\right)$, NOB activity becomes among the dominant processes for all the temperatures together with the last HB denitrification step. With regard to this last observation, the fact that $\mathrm{K}_{\mathrm{N} 2 \mathrm{O}}$, namely the $\mathrm{N}_{2} \mathrm{O}$ half-saturation coefficient for $\mathrm{N}_{2} \mathrm{O}-$ to- $\mathrm{N}_{2}$ reduction by $\mathrm{HB}$, is the most influencing parameter suggests that there is, as a consequence of high $\mathrm{N}_{2} \mathrm{O}$ production by AOB, a very high $\mathrm{N}_{2} \mathrm{O}$ liquid concentration which triggers the last denitrification step. For this reason, it can be said that $\mathrm{AOB}$ denitrification has become for all the temperatures the major contributor to total $\mathrm{N}_{2} \mathrm{O}$ emissions at these oxygen concentrations. On the basis of this, it can be stated that the value of the dissolved oxygen concentration maximizing AOB denitrification can change quite a lot in function of the parameter values used to shape the function;

- at high oxygen concentrations (i.e. $2 \mathrm{mg}(-\mathrm{COD}) \cdot \mathrm{L}^{-1}$ ), the first HB denitrification step emerges among the processes contributing to $\mathrm{N}_{2} \mathrm{O}$ emissions. This indicates that the first denitrification step leads to nitrite accumulation, which triggers the production of $\mathrm{N}_{2} \mathrm{O}$ by HB. Contextually, the last denitrification step emerges as relevant process. Especially at high temperatures, oxygen is found to inhibit the last HB denitrification step. In addition, the NOB growth rate is detected as contributing process able to reduce the $\mathrm{N}_{2} \mathrm{O}$ emissions.

With regard to the temperature effect, it could be noted that the availability of organic biodegradable substrates for the last HB denitrification step is more determining the total $\mathrm{N}_{2} \mathrm{O}$ emissions than the nitrite accumulation under oxygen limiting conditions, when temperature is low. As the temperature increases, 
NOB activity and nitrite accumulation emerges as the main process determining $\mathrm{N}_{2} \mathrm{O}$ emissions. This can be explained by the fact that, as shown in Hellinga et al. [25], AOB maximum specific growth rate is more favoured than NOB maximum specific growth rate by temperature increase.

Table 5: Mean, standard deviation and ratio between them for total $\mathrm{N}_{2} \mathrm{O}$ emissions.

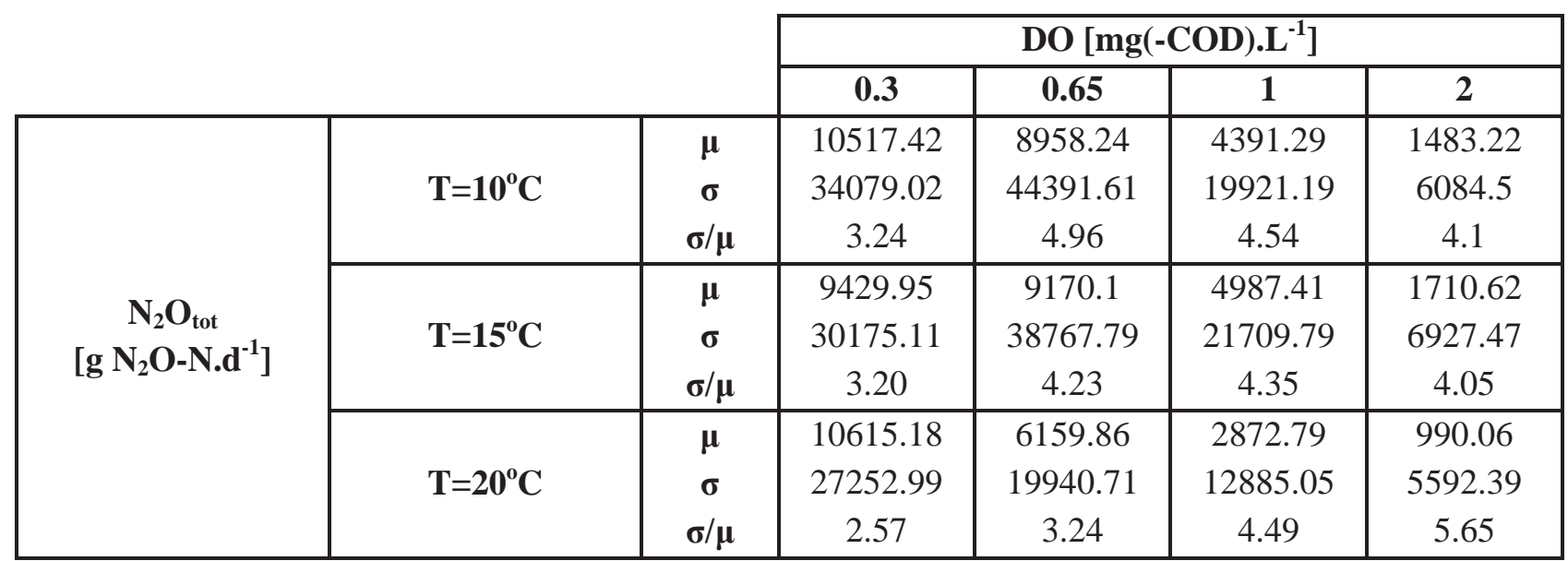

Table 6: Sensitivity analysis results with regard to the ASMG1 parameters for $\mathrm{N}_{2} \mathrm{O}$ emissions at oxygen concentrations in the aerobic zone of 0.3, 0.65, 1 and $2 \mathrm{mg}(-\mathrm{COD}) \cdot \mathrm{L}^{-1}$ and at temperatures of 10,15 and $20^{\circ} \mathrm{C}$. Model parameters are reported in decreasing order of importance: from the parameter having the highest SEE to the one having the lowest. The effect of the parameter on the $\mathrm{N}_{2} \mathrm{O}$ emitted is specified within brackets.

\begin{tabular}{|c|c|c|c|c|c|}
\hline & \multicolumn{4}{|c|}{ DO [mg(-COD). $\left.\mathrm{L}^{-1}\right]$} \\
\hline & & $\mathrm{DO}=0.3$ & DO $=0.65$ & DO $=1$ & $\mathrm{DO}=2$ \\
\hline \multirow{3}{*}{$\begin{array}{c}\text { Total } \\
\mathrm{N}_{2} \mathrm{O} \\
\text { emissions }\end{array}$} & $\mathrm{T}=10^{\circ} \mathrm{C}$ & $\begin{array}{c}\mathrm{K}_{\mathrm{S} 5}(+), \mathrm{n}_{\mathrm{g} 5}(-), \\
\mathrm{K}_{\mathrm{IO}, \mathrm{AOBden} 1}(+), \mathrm{K}_{\mathrm{N} 2 \mathrm{O}} \\
(+), \mathrm{n}_{\mathrm{g} 3}(+) . \\
\end{array}$ & $\mu_{\mathrm{A} 2}(-), \mathrm{K}_{\mathrm{N} 2 \mathrm{O}}(+)$ & $\mathrm{K}_{\mathrm{N} 2 \mathrm{O}}(+)$. & $\begin{array}{c}\mathrm{K}_{\mathrm{N} 2 \mathrm{O}}(+), \mathrm{K}_{\mathrm{S} 2}(-), \mathrm{n}_{\mathrm{g} 2} \\
(+), \mathrm{K}_{\mathrm{FNA}}^{(+),}, \mu_{\mathrm{A} 2}(-), \\
\mathrm{n}_{\mathrm{AOB}}(+) . \\
\end{array}$ \\
\hline & $\mathrm{T}=15^{\circ} \mathrm{C}$ & $\begin{array}{c}\mathrm{K}_{\mathrm{OA} 2}(+), \mathrm{K}_{\mathrm{FNA}, \mathrm{AOB}}(-), \\
\mathrm{K}_{\mathrm{S} 5}(+), \mathrm{K}_{\mathrm{SO}, \mathrm{AOBden} 1}(-), \\
\mathrm{K}_{\mathrm{OH} 5}(-), \mathrm{n}_{\mathrm{g} 5}(-), \mathrm{K}_{\mathrm{S} 3}(-), \\
\mathrm{K}_{\mathrm{N} 2 \mathrm{O}}(+), \mathrm{K}_{\mathrm{OA} 1}(-), \mathrm{b}_{\mathrm{A} 1} \\
(-), \mathrm{b}_{\mathrm{A} 2}(+), . \\
\end{array}$ & $\begin{array}{c}\mu_{\mathrm{A} 2}(-), \mathrm{K}_{\mathrm{OA} 2}(+), \mathrm{K}_{\mathrm{N} 2 \mathrm{O}} \\
(+), \mathrm{f}_{\mathrm{p}}(+)\end{array}$ & $\mathrm{K}_{\mathrm{N} 2 \mathrm{O}}(+), \mathrm{n}_{\mathrm{g} 5}(-)$. & $\begin{array}{c}\mathrm{K}_{\mathrm{S} 2}(-), \mathrm{n}_{\mathrm{g} 2}(+), \mu_{\mathrm{A} 2}(- \\
), \mathrm{n}_{\mathrm{AOB}}(+) .\end{array}$ \\
\hline & $\mathrm{T}=20^{\circ} \mathrm{C}$ & $\begin{array}{c}\mathrm{K}_{\mathrm{OA} 2}(+), \mathrm{K}_{\mathrm{N} 2 \mathrm{O}}(+), \mathrm{K}_{\mathrm{S} 3} \\
(-), \mathrm{K}_{\mathrm{FA}}(-), \mathrm{f}_{\mathrm{P}}(+), \mathrm{b}_{\mathrm{A} 1}(- \\
), \mathrm{K}_{\mathrm{NO} 2}(-) .\end{array}$ & $\mathrm{K}_{\mathrm{N} 2 \mathrm{O}}(+), \mathrm{K}_{\mathrm{FNA}}(+)$. & $\begin{array}{c}\mathrm{K}_{\mathrm{OA} 2}(+), \mathrm{b}_{\mathrm{A} 2}(+), \mu_{\mathrm{A} 2} \\
(-) .\end{array}$ & $\begin{array}{c}\mathrm{K}_{\mathrm{N} 2 \mathrm{O}}(+), \mathrm{K}_{\mathrm{OH} 5}(-), \\
\mathrm{n}_{\mathrm{g} 5}(-), \mathrm{K}_{\mathrm{S} 2}(-), \mu_{\mathrm{A} 2}(- \\
) .\end{array}$ \\
\hline
\end{tabular}




\subsection{The oxygen consumption by microbial activities}

In Table 7 the mean, standard deviation and ratio between them for the amount of oxygen consumed by the three different microbial groups (i.e. $\mathrm{HB}, \mathrm{AOB}$ and $\mathrm{NOB}$ ) and the specific oxygen consumption, namely the total oxygen consumed per unit of total nitrogen removed, are presented. Table 8 shows the model parameters most influencing these uncertain outputs.

As can be noted from the uncertainty analysis results, the three oxygen consumptions have a low propagation of the model parameter uncertainties. However, NOB activity under oxygen-limited conditions has higher uncertainty than the other model outputs. Similarly, the result for specific oxygen consumed is quite uncertain under oxygen-limited conditions.

Looking at the mean values achieved for the oxygen consumed by HB, oxygen competition with autotrophic biomass emerges at low DO. More specifically, when DO is equal to $0.3 \mathrm{mg}$ (-COD). $\mathrm{L}^{-1}$, $\mathrm{HB}$ consumption is the lowest at a temperature of $15^{\circ} \mathrm{C}$ while $\mathrm{AOB}$ and NOB have their highest DO consumption. From the sensitivity analysis results achieved at the same oxygen concentration and operating temperature, it emerges that NOB activity has a negative effect on HB activity. In addition, NOB activity is found to be playing a decisive role also on the oxygen consumption by AOB. At a DO concentration equal to $0.3 \mathrm{mg}(-\mathrm{COD}) \cdot \mathrm{L}^{-1}$, NOB has an increasingly positive effect on the consumption of oxygen by AOB. This can be explained by the fact that at low oxygen concentrations, AOB denitrification is enhanced. This means that a significant fraction of hydroxylamine, produced from AOB-mediated aerobic ammonium oxidation, is oxidized by AOB using nitrite instead of oxygen. If NOB activity increases, nitrite availability will be reduced and thus AOB denitrification will be slowed down. More hydroxylamine will be oxidized with oxygen, which in turn will increase the amount of oxygen consumed by AOB. Competition between HB and NOB occurs also at higher oxygen concentrations. More specifically, as oxygen increases, NOB activity is observed to be limited by the presence of organic biodegradable carbon in the aerobic zone. As a matter of fact, the rate of the first HB denitrification step, where nitrate is reduced to nitrite, is found to positively influence NOB activity. This can be explained by the fact that, when the first reduction step by HB is slowed down, more organic carbon is fed into the aerobic zone, which increases the amount of oxygen consumed by HB and removes it from NOB. As a matter of fact, the rate of aerobic HB activity is detected to have a negative effect on NOB. This explains 
why, for the same operating temperature, when oxygen increases from 0.65 to $2 \mathrm{mg}$ (-COD). $\mathrm{L}^{-1}$, NOB activity decreases due to the prevalence of aerobic HB activity. This indicates that concentrations of oxygen higher than $1 \mathrm{mg}$ (-COD). $\mathrm{L}^{-1}$ in the stream recycled from the last aerobic tank to the anoxic zone should be avoided to preserve high $\mathrm{HB}$ denitrification and preserve NOB activity, helpful for the prevention of $\mathrm{N}_{2} \mathrm{O}$ formation.

The amount of oxygen consumed by $\mathrm{HB}$ and $\mathrm{AOB}$ is found to increase when the oxygen concentration is increased from 1 to $2 \mathrm{mg}$ (-COD). $\mathrm{L}^{-1}$. Furthermore, these two oxygen consumptions are found to be influenced by similar model parameters, as shown in Table 8. Among these, the parameters linked to the biomass decay emerge. As more biomass decays and a larger fraction of these decay products can be reverted into biodegradable organic carbon and ammonium, the higher is the consumption of oxygen by AOB and HB.

With regard to the oxygen consumed per unit of TN removed, excluding the value at DO equal to $0.3 \mathrm{mg}$ (COD). $\mathrm{L}^{-1}$ and a temperature of $10^{\circ} \mathrm{C}$, where uncertainty prevents from considering its mean value, it can be noted that this quantity increases as oxygen increases while it decreases at temperature increases. The oxygen effect is mainly linked to NOB activity. As a matter of fact, as oxygen is increased from 0.3 to 0.65 mg (-COD). $\mathrm{L}^{-1}$, NOB activity increases, which in turn increases the total amount of oxygen consumed and contextually decreases the overall TN removal efficiency due to higher COD demand by heterotrophic denitrifiers. This thesis is confirmed by the sensitivity analysis results which show NOB-related model parameters as the most influencing ones at limited oxygen conditions. On the other side, the effect of temperature is due to the efficiency of HB denitrification. As temperature increases, HB denitrification gets more complete, which improves the TN removal efficiency for the same amount of oxygen consumed. This effect is deduced from the results of the sensitivity analyses performed, which shows the anoxic reduction factor for the hydrolysis of $\mathrm{X}_{\mathrm{S}}\left(\mathrm{n}_{\mathrm{h}}\right)$ and the anoxic reduction factor for the heterotrophic yield $\left(\mathrm{n}_{\mathrm{Y}}\right)$ as the main model parameters reducing the specific oxygen consumption. 
Table 7: Mean value, standard deviation and ratio between them of oxygen consumption values by: (a) HB, (b) AOB, (c) NOB and (d) total oxygen consumption per unit of TN removed.

(a)

\begin{tabular}{|c|c|c|c|c|c|}
\hline & & \multicolumn{4}{|c|}{$\mathrm{O}_{2}$ consumed by $\mathrm{HB}$} \\
\hline \multicolumn{2}{|c|}{ units } & \multicolumn{4}{|c|}{$\left[\mathrm{kg}\left(\mathrm{O}_{2}\right)_{\text {cons }} \cdot \mathrm{d}^{-1}\right]$} \\
\hline \multicolumn{2}{|c|}{ DO [mg (-COD). $\left.\mathrm{L}^{-1}\right]$} & 0.3 & 0.65 & 1 & 2 \\
\hline \multirow{3}{*}{$\mathrm{T}=10^{\circ} \mathrm{C}$} & $\mu$ & 2636.1 & 2269.1 & 2343.4 & 2459 \\
\hline & $\sigma$ & 668.6 & 232.9 & 216.1 & 210.5 \\
\hline & $\sigma / \mu$ & 0.25 & 0.1 & 0.09 & 0.09 \\
\hline \multirow{3}{*}{$\mathrm{T}=15^{\circ} \mathrm{C}$} & $\mu$ & 2587.4 & 2666.8 & 2745.7 & 2859.65 \\
\hline & $\sigma$ & 399.5 & 255 & 237.1 & 230.6 \\
\hline & $\sigma / \mu$ & 0.15 & 0.1 & 0.09 & 0.08 \\
\hline \multirow{3}{*}{$\mathrm{T}=20^{\circ} \mathrm{C}$} & $\mu$ & 2960.6 & 2980.2 & 3052.3 & 3154.5 \\
\hline & $\sigma$ & 429 & 249.8 & 235.6 & 230.9 \\
\hline & $\sigma / \mu$ & 0.14 & 0.08 & 0.08 & 0.07 \\
\hline
\end{tabular}

(b)

\begin{tabular}{|c|c|c|c|c|c|}
\hline & & \multicolumn{4}{|c|}{$\mathrm{O}_{2}$ consumed by AOB } \\
\hline \multicolumn{2}{|c|}{ units } & \multicolumn{4}{|c|}{$\left[\mathrm{kg}\left(\mathrm{O}_{2}\right)_{\text {cons }} \cdot \mathrm{d}^{-1}\right]$} \\
\hline \multicolumn{2}{|c|}{ DO [mg (-COD). $\left.\mathrm{L}^{-1}\right]$} & 0.3 & 0.65 & 1 & 2 \\
\hline $\mathrm{T}=10^{\circ} \mathrm{C}$ & $\begin{array}{c}\mu \\
\sigma \\
\sigma / \mu\end{array}$ & $\begin{array}{c}2186.2 \\
1231.7 \\
0.56\end{array}$ & $\begin{array}{c}2802.5 \\
316.9 \\
0.11\end{array}$ & $\begin{array}{c}2885.9 \\
123.3 \\
0.04\end{array}$ & $\begin{array}{c}2925.2 \\
57.6 \\
0.02\end{array}$ \\
\hline $\mathrm{T}=15^{\circ} \mathrm{C}$ & $\begin{array}{c}\mu \\
\sigma \\
\sigma / \mu\end{array}$ & $\begin{array}{c}2757 \\
355.3 \\
0.13\end{array}$ & $\begin{array}{c}2864 \\
303.3 \\
0.11\end{array}$ & $\begin{array}{c}2926.7 \\
128.3 \\
0.04\end{array}$ & $\begin{array}{c}2955.8 \\
633 \\
0.02\end{array}$ \\
\hline $\mathrm{T}=\mathbf{2 0 ^ { \circ } \mathrm { C }}$ & $\begin{array}{c}\mu \\
\sigma \\
\sigma / \mu\end{array}$ & $\begin{array}{c}2337.1 \\
327 \\
0.14\end{array}$ & $\begin{array}{c}2888.2 \\
234.04 \\
0.08\end{array}$ & $\begin{array}{c}2948.3 \\
141.7 \\
0.05\end{array}$ & $\begin{array}{c}2976.7 \\
65.5 \\
0.02\end{array}$ \\
\hline
\end{tabular}

(c)

\begin{tabular}{|c|c|c|c|c|c|}
\cline { 3 - 6 } \multicolumn{1}{c|}{} & \multicolumn{4}{c|}{ O $_{2}$ consumed by NOB } \\
\hline \multicolumn{2}{c|}{ units } & \multicolumn{4}{c|}{$\left[\mathrm{kg}\left(\mathrm{O}_{2}\right)_{\text {cons }} \cdot \mathrm{d}^{-1}\right]$} \\
\hline DO [mg (-COD). $\mathbf{~}^{-1}$ ] & $\mathbf{0 . 3}$ & $\mathbf{0 . 6 5}$ & $\mathbf{1}$ & $\mathbf{2}$ \\
\hline \multirow{3}{*}{$\mathbf{T}=\mathbf{1 0} \mathbf{C}$} & $\boldsymbol{\mu}$ & 569.4 & 1132.5 & 1152.6 & 1112.7 \\
& $\mathbf{\sigma}$ & 570.95 & 173.3 & 130.9 & 115.8 \\
& $\mathbf{\sigma} / \boldsymbol{\mu}$ & 1 & 0.15 & 0.11 & 0.1 \\
\hline \multirow{2}{*}{$\mathbf{T}=\mathbf{1 5}^{\mathbf{0}} \mathbf{C}$} & $\boldsymbol{\mu}$ & 1052.5 & 1204 & 1178.3 & 1125.4 \\
& $\mathbf{\sigma}$ & 527.15 & 182.5 & 140.1 & 124.5 \\
& $\mathbf{\sigma} / \boldsymbol{\mu}$ & 0.5 & 0.15 & 0.12 & 0.11 \\
\hline $\mathbf{T}=\mathbf{2 0}^{\mathbf{0}} \mathbf{C}$ & $\boldsymbol{\mu}$ & 1046.5 & 1193.4 & 1166 & 1107.3
\end{tabular}




\begin{tabular}{|c|c|c|c|c|c|} 
& $\boldsymbol{\sigma}$ & 571.3 & 172.7 & 122.2 & 90 \\
& $\boldsymbol{\sigma} / \boldsymbol{\mu}$ & 0.55 & 0.14 & 0.1 & 0.08 \\
\hline
\end{tabular}

(d)

\begin{tabular}{|c|c|c|c|c|c|}
\hline & & \multicolumn{4}{|c|}{ Specific oxygen consumption } \\
\hline \multicolumn{2}{|l|}{ units } & \multicolumn{4}{|c|}{$\left[\mathrm{g}\left(\mathrm{O}_{2}\right)_{\text {cons }} \cdot \mathrm{g}^{-1} \mathrm{TN}_{\text {rem }}\right]$} \\
\hline \multicolumn{2}{|c|}{ DO [mg (-COD). $\left.\mathrm{L}^{-1}\right]$} & 0.3 & 0.65 & 1 & 2 \\
\hline \multirow{3}{*}{$\mathrm{T}=10^{\circ} \mathrm{C}$} & $\mu$ & 476.7 & 10.86 & 11.56 & 12.43 \\
\hline & $\boldsymbol{\sigma}$ & 6161.5 & 1.51 & 1.14 & 1.16 \\
\hline & $\sigma / \mu$ & 12.93 & 0.14 & 0.1 & 0.09 \\
\hline \multirow{3}{*}{$\mathrm{T}=15^{\circ} \mathrm{C}$} & $\mu$ & 9.76 & 10.49 & 11.05 & 11.7 \\
\hline & $\boldsymbol{\sigma}$ & 12.03 & 1.3 & 1.08 & 1.09 \\
\hline & $\sigma / \mu$ & 1.23 & 0.12 & 0.1 & 0.09 \\
\hline \multirow{3}{*}{$\mathrm{T}=20^{\circ} \mathrm{C}$} & $\mu$ & 8.35 & 10.2 & 10.7 & 11.06 \\
\hline & $\sigma$ & 1.44 & 1.14 & 1 & 0.98 \\
\hline & $\sigma / \mu$ & 0.17 & 0.11 & 0.09 & 0.09 \\
\hline
\end{tabular}

Table 8: Sensitivity analysis results with regard to the ASMG1 parameters for oxygen consumptions by HB, $\mathrm{AOB}$ and $\mathrm{HB}$, and the total oxygen consumption per unit of TN removed at the temperatures of: (a) $10^{\circ} \mathrm{C}$, (b) $15^{\circ} \mathrm{C}$, and (c) $20^{\circ} \mathrm{C}$.

(a)

\begin{tabular}{|c|c|c|c|c|}
\hline & \multicolumn{4}{|c|}{$\mathrm{T}=10^{\circ} \mathrm{C}$} \\
\hline & $\mathrm{DO}=0.3$ & $\mathrm{DO}=0.65$ & DO=1 & $\mathrm{DO}=2$ \\
\hline $\begin{array}{c}\mathrm{O}_{2} \text { consumption } \\
\text { by } \mathrm{HB}\end{array}$ & $\begin{array}{l}\mathrm{K}_{\mathrm{OA} 1}(+), \mu_{\mathrm{A} 1}(-), \mathrm{K}_{\mathrm{OA} 2} \\
(+), \mu_{\mathrm{A} 2}(-), \mathrm{f}_{\mathrm{P}}(-), \mathrm{b}_{\mathrm{H}}(+) .\end{array}$ & $\begin{array}{c}\mathrm{b}_{\mathrm{H}}(+), \mathrm{Y}_{\mathrm{H}}(-), \mathrm{f}_{\mathrm{P}}(-), \mathrm{K}_{\mathrm{S} 2}(+), \\
\mathrm{K}_{\mathrm{S} 1}(-), \mathrm{n}_{\mathrm{h}}(-), \mathrm{K}_{\mathrm{OH} 2}(-), \mathrm{n}_{\mathrm{g} 2}(- \\
), \mathrm{K}_{\mathrm{NO3}}(+) .\end{array}$ & $\begin{array}{c}\mathrm{b}_{\mathrm{H}}(+), \mathrm{Y}_{\mathrm{H}}(-), \mathrm{f}_{\mathrm{P}}(-), \\
\mathrm{K}_{\mathrm{S} 2}(+), \mathrm{n}_{\mathrm{h}}(-), \mathrm{K}_{\mathrm{S} 1}(-), \\
\mathrm{n}_{\mathrm{g} 2}(-), \mathrm{K}_{\mathrm{OH} 2}(-), \mathrm{K}_{\mathrm{NO} 3} \\
(+) .\end{array}$ & $\begin{array}{l}\mathrm{b}_{\mathrm{H}}(+), \mathrm{Y}_{\mathrm{H}}(-), \mathrm{f}_{\mathrm{p}}(-), \mathrm{n}_{\mathrm{h}}(- \\
), \mathrm{K}_{\mathrm{S} 2}(+), \mathrm{K}_{\mathrm{S} 1}(-), \mathrm{n}_{\mathrm{g} 2}(-) .\end{array}$ \\
\hline $\begin{array}{l}\mathrm{O}_{2} \text { consumption } \\
\text { by } \mathrm{AOB}\end{array}$ & $\mathrm{K}_{\mathrm{OA} 1}(-), \mu_{\mathrm{A} 1}(+), \mathrm{Y}_{\mathrm{H}}(-)$. & $\begin{array}{c}\mathrm{K}_{\mathrm{FNA}, \mathrm{AOB}}(+), \mathrm{K}_{\mathrm{OA} 2}(-), \mathrm{n}_{\mathrm{AOB}} \\
(-), \mathrm{f}_{\mathrm{P}}(-), \mu_{\mathrm{A} 2}(+) .\end{array}$ & $\begin{array}{c}\mathrm{f}_{\mathrm{P}}(-), \mathrm{n}_{\mathrm{AOB}}(-), \mathrm{i}_{\mathrm{XP}}(-), \\
\mathrm{i}_{\mathrm{XB}}(+), \mathrm{K}_{\mathrm{OA} 2}(-), \mathrm{Y}_{\mathrm{H}} \\
(-) .^{*}\end{array}$ & $\begin{array}{l}\mathrm{f}_{\mathrm{P}}(-), \mathrm{i}_{\mathrm{XP}}(-), \mathrm{i}_{\mathrm{XB}}(+), \mathrm{Y}_{\mathrm{H}} \\
(-), \mathrm{k}_{\mathrm{a}}(+), \mathrm{K}_{\mathrm{FA}}(-)\end{array}$ \\
\hline $\begin{array}{l}\mathrm{O}_{2} \text { consumption } \\
\text { by NOB }\end{array}$ & $\begin{array}{c}\mathrm{K}_{\mathrm{OA} 2}(-), \mathrm{K}_{\mathrm{OA} 1}(-), \mu_{\mathrm{A} 2} \\
(+), \mu_{\mathrm{A} 1}(+), \mathrm{Y}_{\mathrm{H}}(-) \\
\mathrm{K}_{\mathrm{I} 3 \mathrm{NO}}(-), \mathrm{K}_{\mathrm{FNA}}(-)\end{array}$ & $\begin{array}{c}\mathrm{K}_{\mathrm{S} 2}(-), \mathrm{K}_{\mathrm{OH} 2}(+), \mathrm{K}_{\mathrm{S} 1}(+), \\
\mathrm{K}_{\mathrm{OA} 2}(-), \mathrm{n}_{\mathrm{g} 2}(+), \mu_{\mathrm{A} 2}(+), \mathrm{b}_{\mathrm{H}} \\
(+), \mathrm{K}_{\mathrm{FNA}, \mathrm{AOB}}(+), \mathrm{f}_{\mathrm{p}}(-), \\
\mathrm{K}_{\mathrm{NO} 2}(+) .\end{array}$ & $\begin{array}{c}\mathrm{K}_{\mathrm{S} 2}(-), \mathrm{K}_{\mathrm{OH} 2}(+), \mathrm{K}_{\mathrm{S} 1} \\
(+), \mathrm{n}_{\mathrm{g} 2}(+), \mathrm{K}_{\mathrm{S} 4}(+), \\
\mathrm{K}_{\mathrm{I} 4 \mathrm{NO}}(-), \mathrm{n}_{\mathrm{Y}}(-), \mathrm{K}_{\mathrm{OA} 2} \\
(-), \mathrm{K}_{\mathrm{NO} 2}(+) .\end{array}$ & $\begin{array}{c}\mathrm{K}_{\mathrm{S} 2}(-), \mathrm{K}_{\mathrm{OH} 2}(+), \mathrm{K}_{\mathrm{IANO}}(- \\
), \mathrm{n}_{\mathrm{g} 2}(+), \mathrm{K}_{\mathrm{S} 1}(+), \mathrm{K}_{\mathrm{S} 4} \\
(+), \mathrm{n}_{\mathrm{Y}}(-), \mathrm{K}_{\mathrm{FA}}(-) .\end{array}$ \\
\hline $\begin{array}{c}\text { Specific } \mathrm{O}_{2} \\
\text { consumption }\end{array}$ & $\mathrm{b}_{\mathrm{A} 1}(+) . *$ & $\begin{array}{c}\mathrm{n}_{\mathrm{h}}(-), \mathrm{K}_{\mathrm{OA} 2}(-), \mathrm{n}_{\mathrm{Y}}(+), \mu_{\mathrm{A} 2} \\
(+), \mathrm{f}_{\mathrm{P}}(-), \mathrm{b}_{\mathrm{H}}(+), \mathrm{K}_{\mathrm{FNA}, \mathrm{AOB}} \\
(+), \mathrm{n}_{\mathrm{AOB}}(-), \mu_{\mathrm{A} 1}(-), \mathrm{K}_{\mathrm{NO} 2} \\
(+), \mathrm{n}_{\mathrm{g} 3}(-), \mathrm{K}_{\mathrm{OA} 1}(+), \mathrm{i}_{\mathrm{XP}}(-)\end{array}$ & $\begin{array}{c}\mathrm{n}_{\mathrm{h}}(-), \mathrm{n}_{\mathrm{Y}}(+), \mathrm{f}_{\mathrm{P}}(-), \mathrm{k}_{\mathrm{h}} \\
(-), \mathrm{K}_{\mathrm{OA} 2}(-), \mu_{\mathrm{A} 2}(+), \\
\mathrm{K}_{\mathrm{NO} 2}(+), \mathrm{K}_{\mathrm{S} 1}(-), \mathrm{i}_{\mathrm{XP}} \\
(-), \mathrm{n}_{\mathrm{g} 3}(-), \mathrm{K}_{\mathrm{NO}}(+), \\
\mathrm{b}_{\mathrm{H}}(+), \mathrm{K}_{\mathrm{S} 3}(+), \mathrm{i}_{\mathrm{XB}} \\
(+), \mu_{\mathrm{A} 1}(-) .\end{array}$ & $\begin{array}{c}\mathrm{n}_{\mathrm{h}}(-), \mathrm{n}_{\mathrm{Y}}(+), \mathrm{f}_{\mathrm{P}}(-), \mathrm{k}_{\mathrm{h}}(-), \\
\mathrm{K}_{\mathrm{S} 1}(-), \mathrm{i}_{\mathrm{XB}}(+), \mathrm{i}_{\mathrm{XP}}(-), \\
\mathrm{Y}_{\mathrm{H}}(+), \mathrm{K}_{\mathrm{NO} 3}(+), \mathrm{K}_{\mathrm{S} 3}(+), \\
\mathrm{K}_{\mathrm{OH} 1}(-), \mathrm{K}_{\mathrm{I} 4 \mathrm{NO}}(-), \mathrm{K}_{\mathrm{S} 4} \\
(+), \mathrm{K}_{\mathrm{OA} 1}(+), \mathrm{K}_{\mathrm{NO} 2}(+) .\end{array}$ \\
\hline
\end{tabular}

(b)

\begin{tabular}{|c|c|c|c|c|}
\hline & \multicolumn{4}{|c|}{$\mathrm{T}=15^{\circ} \mathrm{C}$} \\
\hline & $\mathrm{DO}=0.3$ & $\mathrm{DO}=0.65$ & $\mathrm{DO}=1$ & $\mathrm{DO}=2$ \\
\hline $\mathrm{O}_{2}$ consumption by & $\mathrm{K}_{\mathrm{OA} 2}(+), \mu_{\mathrm{A} 2}(-), \mathrm{f}_{\mathrm{P}}(-$ & $\mathrm{f}_{\mathrm{P}}(-), \mathrm{b}_{\mathrm{H}}(+), \mathrm{Y}_{\mathrm{H}}(-), \mathrm{K}_{\mathrm{S} 2}$ & $\mathrm{f}_{\mathrm{P}}(-), \mathrm{b}_{\mathrm{H}}(+), \mathrm{Y}_{\mathrm{H}}(-), \mathrm{K}_{\mathrm{S} 2}$ & $\mathrm{f}_{\mathrm{P}}(-), \mathrm{b}_{\mathrm{H}}(+), \mathrm{Y}_{\mathrm{H}}(-), \mathrm{n}_{\mathrm{h}}(-$ \\
\hline
\end{tabular}




\begin{tabular}{|c|c|c|c|c|}
\hline HB & $\begin{array}{c}\text { ), } \mathrm{K}_{\mathrm{S} 2}(+), \mathrm{K}_{\mathrm{S} 1}(-), \mathrm{b}_{\mathrm{H}} \\
(+), \mathrm{Y}_{\mathrm{H}}(-), \mathrm{n}_{\mathrm{g} 2}(-), \\
\mathrm{K}_{\mathrm{OH} 1}(-), \mathrm{b}_{\mathrm{A} 2}(+) . \\
\end{array}$ & $\begin{array}{c}(+), \mathrm{K}_{\mathrm{S} 1}(-), \mathrm{n}_{\mathrm{h}}(-), \mathrm{K}_{\mathrm{OH} 2}(- \\
), \mathrm{n}_{\mathrm{g} 2}(-), \mathrm{K}_{\mathrm{NO} 3}(+)\end{array}$ & $\begin{array}{l}(+), \mathrm{n}_{\mathrm{h}}(-), \mathrm{K}_{\mathrm{S} 1}(-), \mathrm{n}_{\mathrm{g} 2}(-), \\
\mathrm{K}_{\mathrm{OH} 2}(-), \mathrm{K}_{\mathrm{NO} 3}(+), \mathrm{k}_{\mathrm{h}}(-)\end{array}$ & $\begin{array}{c}\text { ), } \mathrm{K}_{\mathrm{S} 2}(+), \mathrm{K}_{\mathrm{S} 1}(-), \mathrm{n}_{\mathrm{g} 2}(-), \\
\mathrm{k}_{\mathrm{h}}(-), \mathrm{K}_{\mathrm{NO} 3}(+) .\end{array}$ \\
\hline $\begin{array}{c}\mathrm{O}_{2} \text { consumption by } \\
\text { AOB }\end{array}$ & $\begin{array}{c}\mathrm{n}_{\mathrm{AOB}}(-), \mathrm{K}_{\mathrm{SO}, \mathrm{AOBden} 1} \\
(+), \mathrm{K}_{\mathrm{OA} 2}(-) .^{*}\end{array}$ & $\begin{array}{c}\mathrm{K}_{\mathrm{FNA}, \mathrm{AOB}}(+), \mathrm{f}_{\mathrm{P}}(-), \mathrm{K}_{\mathrm{OA} 2} \\
(-), \mathrm{n}_{\mathrm{AOB}}(-), \mathrm{K}_{\mathrm{IO}, \mathrm{AOBDen} 1} \\
(-), \mathrm{b}_{\mathrm{A} 2}(-) .{ }^{*}\end{array}$ & $\begin{array}{c}\mathrm{f}_{\mathrm{P}}(-), \mathrm{i}_{\mathrm{XP}}(-), \mathrm{n}_{\mathrm{AOB}}(-), \\
\mathrm{K}_{\mathrm{FNA}, \mathrm{AOB}}(+), \mathrm{i}_{\mathrm{XB}}(+), \\
\mathrm{K}_{\mathrm{I} 4 \mathrm{NO}}(+), \mathrm{Y}_{\mathrm{H}}(-), \mathrm{K}_{\mathrm{S} 4}(-), \\
\mathrm{K}_{\mathrm{I} \text { INO }}(-), \mu_{\mathrm{H}}(-), \\
\mathrm{K}_{\mathrm{IO}, \mathrm{AOBDen} 1}(-) . \\
\end{array}$ & $\begin{array}{c}\mathrm{f}_{\mathrm{P}}(-), \mathrm{i}_{\mathrm{XP}}(-), \mathrm{i}_{\mathrm{XB}}(+), \mathrm{Y}_{\mathrm{H}} \\
(-), \mathrm{k}_{\mathrm{a}}(+)\end{array}$ \\
\hline $\begin{array}{c}\mathrm{O}_{2} \text { consumption by } \\
\text { NOB }\end{array}$ & $\begin{array}{c}\mathrm{K}_{\mathrm{OA} 2}(-), \mu_{\mathrm{A} 2}(+), \mathrm{K}_{\mathrm{S} 2} \\
(-), \mathrm{b}_{\mathrm{A} 2}(-), \mathrm{n}_{\mathrm{g} 2}(+), \\
\mathrm{K}_{\mathrm{OH} 1}(+), \mathrm{K}_{\mathrm{S} 1}(+) \\
\mathrm{K}_{\mathrm{OH} 2}(+)\end{array}$ & $\begin{array}{c}\mathrm{K}_{\mathrm{S} 2}(-), \mathrm{K}_{\mathrm{OH} 2}(+), \mathrm{K}_{\mathrm{S} 1} \\
(+), \mathrm{K}_{\mathrm{OA} 2}(-), \mu_{\mathrm{A} 2}(+), \mathrm{n}_{\mathrm{g} 2} \\
(+), \mathrm{f}_{\mathrm{P}}(-), \mathrm{K}_{\mathrm{FNA}, \mathrm{AOB}}(+)\end{array}$ & $\begin{array}{c}\mathrm{K}_{\mathrm{S} 2}(-), \mathrm{K}_{\mathrm{OH} 2}(+), \mathrm{K}_{\mathrm{S} 1}(+), \\
\mathrm{n}_{\mathrm{g} 2}(+), \mathrm{f}_{\mathrm{P}}(-), \mathrm{K}_{\mathrm{I} 4 \mathrm{NO}}(-), \\
\mathrm{K}_{\mathrm{S} 4}(+) .\end{array}$ & $\begin{array}{c}\mathrm{K}_{\mathrm{S} 2}(-), \mathrm{K}_{\mathrm{OH} 2}(+), \mathrm{K}_{\mathrm{I} 4 \mathrm{NO}} \\
(-), \mathrm{K}_{\mathrm{S} 4}(+), \mathrm{n}_{\mathrm{g} 2}(+), \mathrm{K}_{\mathrm{S} 1} \\
(+), \mathrm{K}_{\mathrm{S} 5}(-), \mathrm{n}_{\mathrm{g} 4}(-), \mathrm{n}_{\mathrm{Y}}(-), \\
\mathrm{K}_{\mathrm{I} 3 \mathrm{NO}}(+), \mathrm{f}_{\mathrm{P}}(-) .\end{array}$ \\
\hline $\begin{array}{c}\text { Specific } \mathrm{O}_{2} \\
\text { consumption }\end{array}$ & $\begin{array}{c}\mathrm{K}_{\mathrm{OA} 2}(-), \mathrm{n}_{\mathrm{AOB}}(-), \mu_{\mathrm{A} 2} \\
(+), \mathrm{K}_{\mathrm{SO}, \mathrm{AOBDen} 1} \\
(+), \mathrm{K}_{\mathrm{NO} 3}(+), \mathrm{b}_{\mathrm{A} 2}(-), \\
\mathrm{K}_{\mathrm{S} 1}(-), \mathrm{n}_{\mathrm{h}}(-) .^{*}\end{array}$ & $\begin{array}{c}\mathrm{n}_{\mathrm{h}}(-), \mathrm{K}_{\mathrm{OA} 2}(-), \mathrm{f}_{\mathrm{P}}(-), \mu_{\mathrm{A} 2} \\
(+), \mathrm{n}_{\mathrm{Y}}(+), \mathrm{b}_{\mathrm{H}}(+), \\
\mathrm{K}_{\mathrm{FNA}, \mathrm{AOB}}(+), \mathrm{K}_{\mathrm{NO} 3}(+), \\
\mu_{\mathrm{A} 1}(-), \mathrm{k}_{\mathrm{h}}(-), \mathrm{n}_{\mathrm{AOB}}(-), \\
\mathrm{i}_{\mathrm{XP}}(-), \mu_{\mathrm{H}}(-), \mathrm{K}_{\mathrm{NO} 2}(+), \\
\mathrm{K}_{\mathrm{OA} 1}(+)\end{array}$ & $\begin{array}{c}\mathrm{n}_{\mathrm{h}}(-), \mathrm{f}_{\mathrm{P}}(-), \mathrm{n}_{\mathrm{Y}}(+), \mathrm{k}_{\mathrm{h}}(-), \\
\mathrm{b}_{\mathrm{H}}(+), \mathrm{K}_{\mathrm{NO} O}(+), \mathrm{i}_{\mathrm{XP}}(-), \\
\mu_{\mathrm{A} 2}(+), \mathrm{n}_{\mathrm{g} 3}(-), \mathrm{K}_{\mathrm{OA} 2}(-), \\
\mathrm{i}_{\mathrm{XB}}(+), \mathrm{K}_{\mathrm{S} 1}(-), \mathrm{K}_{\mathrm{N} 2 \mathrm{O}}(+) .\end{array}$ & $\begin{array}{c}\mathrm{n}_{\mathrm{h}}(-), \mathrm{n}_{\mathrm{Y}}(+), \mathrm{k}_{\mathrm{h}}(-), \mathrm{f}_{\mathrm{P}}(- \\
), \mathrm{K}_{\mathrm{NO} 3}(+), \mathrm{i}_{\mathrm{XP}}(-), \mathrm{K}_{\mathrm{S} 1}(- \\
), \mathrm{b}_{\mathrm{H}}(+), \mathrm{i}_{\mathrm{XB}}(+), \mathrm{K}_{\mathrm{I} 4 \mathrm{NO}}(- \\
), \mathrm{K}_{\mathrm{S} 4}(+), \mathrm{K}_{\mathrm{OA} 1}(+), \mathrm{K}_{\mathrm{OH} 1} \\
(-) .\end{array}$ \\
\hline
\end{tabular}

(c)

\begin{tabular}{|c|c|c|c|c|}
\hline & \multicolumn{4}{|c|}{$\mathrm{T}=20^{\circ} \mathrm{C}$} \\
\hline & $\mathrm{DO}=0.3$ & DO $=0.65$ & DO=1 & $\mathrm{DO}=2$ \\
\hline $\begin{array}{c}\mathrm{O}_{2} \text { consumption by } \\
\mathrm{HB}\end{array}$ & $\begin{array}{c}\mathrm{K}_{\mathrm{OA} 2}(+), \mu_{\mathrm{A} 2}(-), \mathrm{f}_{\mathrm{P}}, \\
\mathrm{Y}_{\mathrm{H}}(-), \mathrm{K}_{\mathrm{S} 2}(+), \mathrm{K}_{\mathrm{S} 1}(- \\
), \mathrm{b}_{\mathrm{A} 2}(+), \mathrm{b}_{\mathrm{H}}(+), \\
\mathrm{K}_{\mathrm{NO} 3}(+), \mathrm{K}_{\mathrm{OH} 1}(-), \\
\mathrm{K}_{\mathrm{OH} 2}(-) .\end{array}$ & $\begin{array}{c}\mathrm{f}_{\mathrm{P}}(-), \mathrm{K}_{\mathrm{S} 2}(+), \mathrm{b}_{\mathrm{H}}(+), \mathrm{Y}_{\mathrm{H}} \\
(-), \mathrm{K}_{\mathrm{S} 1}(-), \mathrm{K}_{\mathrm{OH} 2}(-), \mathrm{n}_{\mathrm{g} 2}(- \\
), \mathrm{K}_{\mathrm{NO} 3}(+), \mathrm{n}_{\mathrm{h}}(-) .\end{array}$ & $\begin{array}{c}\mathrm{f}_{\mathrm{P}}(-), \mathrm{b}_{\mathrm{H}}(+), \mathrm{Y}_{\mathrm{H}}(-), \mathrm{K}_{\mathrm{S} 2} \\
(+), \mathrm{K}_{\mathrm{S} 1}(-), \mathrm{n}_{\mathrm{h}}(-), \mathrm{K}_{\mathrm{OH} 2} \\
(-), \mathrm{n}_{\mathrm{g} 2}(-), \mathrm{K}_{\mathrm{NO} 3}(+) .\end{array}$ & $\begin{array}{c}\mathrm{f}_{\mathrm{P}}(-), \mathrm{b}_{\mathrm{H}}(+), \mathrm{Y}_{\mathrm{H}}(-), \mathrm{K}_{\mathrm{S} 2} \\
(+), \mathrm{n}_{\mathrm{h}}(-), \mathrm{K}_{\mathrm{S} 1}(-), \mathrm{K}_{\mathrm{NO} 3} \\
(+), \mathrm{k}_{\mathrm{h}}(-), \mathrm{n}_{\mathrm{g} 2}(-) .\end{array}$ \\
\hline $\begin{array}{c}\mathrm{O}_{2} \text { consumption by } \\
\text { AOB }\end{array}$ & $\begin{array}{c}\mu_{\mathrm{A} 2}(+), \mathrm{K}_{\mathrm{OA} 2}(-), \\
\mathrm{K}_{\mathrm{SNO}, \mathrm{AOB}}(+), \mathrm{f}_{\mathrm{P}}(-) .^{*}\end{array}$ & $\begin{array}{c}\mathrm{i}_{\mathrm{XP}}(-), \mathrm{i}_{\mathrm{XB}}(+), \mathrm{b}_{\mathrm{A} 2}(-), \mathrm{Y}_{\mathrm{H}} \\
(-), \mathrm{k}_{\mathrm{a}}(+), \mu_{\mathrm{A} 1}(-), \\
\mathrm{K}_{\mathrm{IO}, \mathrm{AOBden} 1}(-), \mathrm{K}_{\mathrm{FA}, \mathrm{AOB}} \\
(+), \mathrm{K}_{\mathrm{FNA}}(-), \mathrm{n}_{\mathrm{Y}}(-) .^{*}\end{array}$ & $\begin{array}{c}\mathrm{f}_{\mathrm{P}}(-), \mathrm{i}_{\mathrm{XB}}(+), \mathrm{Y}_{\mathrm{H}}(-), \\
\mathrm{n}_{\mathrm{AOB}}(-), \mathrm{K}_{\mathrm{OA} 2}(-), \mathrm{i}_{\mathrm{XP}}(-), \\
\mathrm{K}_{\mathrm{FNA}, \mathrm{AOB}}(+), \mathrm{b}_{\mathrm{A} 2}(-), \\
\mathrm{K}_{\mathrm{OH} 4}(+), \mathrm{K}_{\mathrm{S} 2}(-), \\
\mathrm{K}_{\mathrm{FA}, \mathrm{AOB}}(+), \mathrm{K}_{\mathrm{SO}, \mathrm{AOBDen} 1} \\
(-) .\end{array}$ & $\begin{array}{c}\mathrm{f}_{\mathrm{P}}(-), \mathrm{i}_{\mathrm{XP}}(-), \mathrm{i}_{\mathrm{XB}}(+), \mathrm{Y}_{\mathrm{H}} \\
(-), \mathrm{k}_{\mathrm{a}}(+) .\end{array}$ \\
\hline $\begin{array}{c}\mathrm{O}_{2} \text { consumption by } \\
\text { NOB }\end{array}$ & $\begin{array}{c}\mathrm{K}_{\mathrm{OA} 2}(-), \mu_{\mathrm{A} 2}(+), \mathrm{b}_{\mathrm{A} 2} \\
(-), \mathrm{K}_{\mathrm{S} 2}(-), \mathrm{f}_{\mathrm{P}}(-), \\
\mathrm{K}_{\mathrm{OA} 1}(+), \mathrm{K}_{\mathrm{OH} 2}(+), \\
\mathrm{K}_{\mathrm{NO} 3}(-) .\end{array}$ & $\begin{array}{c}\mathrm{K}_{\mathrm{S} 2}(-), \mathrm{K}_{\mathrm{OH} 2}(+), \mathrm{K}_{\mathrm{OA} 2}(- \\
), \mathrm{K}_{\mathrm{S} 1}(+), \mu_{\mathrm{A} 2}(+), \mathrm{n}_{\mathrm{g} 2}(+), \\
\mathrm{f}_{\mathrm{P}}(-), \mathrm{K}_{\mathrm{FNA}, \mathrm{AOB}}(+), \mathrm{b}_{\mathrm{A} 2}(- \\
), \mathrm{K}_{\mathrm{OA} 1}(+), \mathrm{Y}_{\mathrm{H}}(-) .\end{array}$ & $\begin{array}{c}\mathrm{K}_{\mathrm{S} 2(-)}, \mathrm{K}_{\mathrm{S} 1(+)}, \mathrm{K}_{\mathrm{OH} 2(+)}, \\
\mathrm{n}_{\mathrm{g} 2(+)}, \mathrm{f}_{\mathrm{P}(-)}, \mathrm{K}_{\mathrm{OA} 2(-)}, \\
\mathrm{K}_{\mathrm{FNA}, \mathrm{AOB}(+)}, \mu_{\mathrm{A} 2(+)}, \mathrm{Y}_{\mathrm{H}(-} \\
), \mathrm{K}_{\mathrm{OA} 1(+)}\end{array}$ & $\begin{array}{c}\mathrm{K}_{\mathrm{S} 2}(-), \mathrm{K}_{\mathrm{OH} 2}(+), \mathrm{K}_{\mathrm{S} 1} \\
(+), \mathrm{n}_{\mathrm{g} 2}(+), \mathrm{f}_{\mathrm{P}}(-), \mathrm{K}_{\mathrm{S} 3} \\
(+), \mathrm{K}_{\mathrm{I} 4 \mathrm{NO}}(-), \mathrm{K}_{\mathrm{NO} 3}(-), \\
\mathrm{i}_{\mathrm{XB}}(+), \mathrm{K}_{\mathrm{OA} 1}(+) .\end{array}$ \\
\hline $\begin{array}{c}\text { Specific } \mathrm{O}_{2} \\
\text { consumption }\end{array}$ & $\begin{array}{c}\mathrm{K}_{\mathrm{OA} 2}(-), \mu_{\mathrm{A} 2}(+), \mathrm{f}_{\mathrm{P}}(- \\
), \mathrm{K}_{\mathrm{OA} 1}(+), \mathrm{b}_{\mathrm{A} 2}(-), \\
\mu_{\mathrm{A} 1}(-), \mathrm{k}_{\mathrm{h}}(-), \\
\mathrm{K}_{\mathrm{SO}, \mathrm{AOBden} 1}(+), \mathrm{b}_{\mathrm{H}} \\
(+) .\end{array}$ & $\begin{array}{c}\mathrm{K}_{\mathrm{OA} 2}(-), \mathrm{f}_{\mathrm{P}}(-), \mathrm{n}_{\mathrm{h}}(-), \mu_{\mathrm{A} 2} \\
(+), \mathrm{k}_{\mathrm{h}}(-), \mathrm{K}_{\mathrm{FNA}, \mathrm{AOB}}(+), \\
\mathrm{n}_{\mathrm{Y}}(+), \mathrm{b}_{\mathrm{H}}(+), \mathrm{Y}_{\mathrm{H}}(-), \mathrm{b}_{\mathrm{A} 2} \\
(-), \mathrm{K}_{\mathrm{NO} 3}(+), \mathrm{i}_{\mathrm{XB}}(+), \mathrm{n}_{\mathrm{AOB}} \\
(-), \mathrm{K}_{\mathrm{OA} 1}(+) .\end{array}$ & $\begin{array}{c}\mathrm{n}_{\mathrm{h}}(-), \mathrm{f}_{\mathrm{P}}(-), \mathrm{k}_{\mathrm{h}}(-), \mathrm{n}_{\mathrm{Y}}(+), \\
\mathrm{K}_{\mathrm{OA} 2}(-), \mathrm{K}_{\mathrm{NO} 3}(+), \mathrm{b}_{\mathrm{H}} \\
(+), \mathrm{i}_{\mathrm{XB}}(+), \mathrm{K}_{\mathrm{FNA}, \mathrm{AOB}}(+), \\
\mathrm{Y}_{\mathrm{H}}(-), \mu_{\mathrm{A} 2}(+), \mathrm{n}_{\mathrm{AOB}}(-), \\
\mathrm{K}_{\mathrm{OA} 1}(+) .\end{array}$ & $\begin{array}{c}\mathrm{n}_{\mathrm{h}}(-), \mathrm{f}_{\mathrm{P}}(-), \mathrm{n}_{\mathrm{Y}}(+), \mathrm{k}_{\mathrm{h}}(- \\
), \mathrm{K}_{\mathrm{NO} 3}(+), \mathrm{i}_{\mathrm{XB}}(+), \mathrm{b}_{\mathrm{H}} \\
(+), \mu_{\mathrm{H}}(-), \mathrm{i}_{\mathrm{XP}}(-), \mathrm{K}_{\mathrm{S} 2} \\
(+), \mathrm{K}_{\mathrm{OA} 1}(+), \mathrm{K}_{\mathrm{OH} 1}(-) .\end{array}$ \\
\hline
\end{tabular}

* results from sensitivity analysis according to the MS procedure. 


\subsection{Comparison of the behaviours observed against measurements in literature}

The present work uses a specific mathematical formulation of a biochemical wastewater treatment model to derive the biological mechanisms determining the $\mathrm{N}_{2} \mathrm{O}$ emission dynamics, the TN removal efficiency and the oxygen consumptions in pre-denitrification WWTPs. Although the observations achieved can be considered independent from parameter uncertainties, there can still be discrepancies between the model and the reality of the WWTPs due to the mathematical structure of the model and the plant configuration. Therefore, to assess the reliability of the identified biological mechanisms determining the TN removal efficiency, the oxygen consumptions and the $\mathrm{N}_{2} \mathrm{O}$ emissions, it becomes important to consider the collected WWTP data reflecting real full-scale applications. Table 9 shows the confirmation of some of the observations obtained through the present work by practical wastewater treatment plant experiences from the literature.

Table 9: Feedback on the observations obtained during the sensitivity analyses on TN removal efficiency and $\mathrm{N}_{2} \mathrm{O}$ emissions from real plant experiences.

\begin{tabular}{|c|c|}
\hline $\begin{array}{c}\text { OBSERVATIONS FROM SENSITIVITY } \\
\text { ANALYSES }\end{array}$ & REAL PLANT EXPERIENCES \\
\hline TN removal efficiency increases with temperature & Zhang et al. [26] \\
Kim et al. [27]
\end{tabular}


One of the main conclusions from the studies presented in Table 9 is the fact that low oxygen availability and/or accumulation of nitrites are the main causes of high $\mathrm{N}_{2} \mathrm{O}$ emissions. More specifically, the relative rate of NOB activity over AOB activity was found by Foley et al. [4] to determine nitrite accumulation and consequently nitrous oxide production. A drop of the oxygen concentration along with spikes of influent TKN have been attributed to causing nitrite peaks and thus trigger AOB denitrification. Concentrations of nitrite higher than 0.3-0.5 mg N.L $\mathrm{L}^{-1}$ have been found to trigger $\mathrm{N}_{2} \mathrm{O}$ production. This is compatible with the results of our study (see Figure A7 in SI). It is here important to point out that Foley et al. [4] gave this conclusion based on data obtained from six full-scale WWTPs. There are additional statements based on other experiences which support the findings presented in this work. For instance, the study by Sun et al. [28] performed in both full-scale and pilot plants led to concluding that ensuring enough oxygenation to have complete nitrification (i.e. complete conversion of influent ammonium into nitrate without accumulation of the intermediary compound nitrite) is the key for preventing $\mathrm{N}_{2} \mathrm{O}$ production. In the same work the increase of oxygen supply is suggested to be monitored in order to avoid inhibition of heterotrophic denitrification in the anoxic zone, which is also one of the findings of the present research. Similarly, based on measurements from a full-scale carousel reactor, Daelman et al. [29] identified AOB denitrification as the main $\mathrm{N}_{2} \mathrm{O}$ producing pathway due to the clear positive correlation between nitrite concentrations and nitrous oxide emissions. On the basis of this, the same author suggested control of the oxygen concentration to avoid nitrite accumulation and the consequent $\mathrm{N}_{2} \mathrm{O}$ production. Similarly, AOB denitrification was found by Aboobakar et al. [2] to occur in aerobic zones as BOD was progressively depleted and nitrification started taking place. The same full-scale measurement campaign found a clear negative correlation between oxygen concentration and nitrous oxide emission. It was more specifically found that oxygen concentrations lower than $1.5 \mathrm{mg}$ DO.L $\mathrm{L}^{-1}$ can trigger increased $\mathrm{N}_{2} \mathrm{O}$ emissions. This is congruent with the findings of our study (see Figure A6 in the SI). Ahn et al. [6] deduced from a survey on several full-scale WWTPs that high nitrite and ammonium concentrations can determine most of the $\mathrm{N}_{2} \mathrm{O}$ produced by AOB. Stenström et al. [30] found as well from full-scale plants measurements that AOB denitrification is one of the main $\mathrm{N}_{2} \mathrm{O}$ producing processes, triggered by low oxygen concentration $\left(<1-1.5 \mathrm{mg}\right.$ DO. $\left.\mathrm{L}^{-1}\right)$ leading in turn to nitrite accumulation. In addition, there are several lab-scale measurements supporting the findings of the present 
work $[22,32,31,34-36,33,37]$. With regards to the effect of temperature, there is no existing work specifically studying the global effect of temperature on $\mathrm{N}_{2} \mathrm{O}$ emissions. Only Ahn et al. [6] have suggested that the effect of temperature may vary according to the plant configuration, where WWTPs designed not to have nitrification will see a negative effect of temperature on $\mathrm{N}_{2} \mathrm{O}$ emissions while WWTPs designed to have nitrification will see a positive effect of temperature on $\mathrm{N}_{2} \mathrm{O}$ emissions. Daelman et al. [29], though suggesting a negative effect of temperature of $\mathrm{N}_{2} \mathrm{O}$ emissions, has not been able to identify any correlation. The present study found that $\mathrm{N}_{2} \mathrm{O}$ emissions are actually triggered by temperature using the default model parameters. However, no correlation between $\mathrm{N}_{2} \mathrm{O}$ and temperature was able to be identified through the uncertainty analysis by perturbing the parameter values. The temperature effect needs therefore to be investigated further in the future.

\subsection{A novel control idea for low $\mathrm{N}_{2} \mathrm{O}$ emissions}

On the basis of the results achieved, a control strategy minimizing $\mathrm{N}_{2} \mathrm{O}$ emissions can be designed. This controller should be specifically built up in order to establish a trade-off oxygen regime slowing down $\mathrm{N}_{2} \mathrm{O}$ production from AOB denitrification and allowing a complete HB denitrification in function of the influent Total Kjedhal Nitrogen (TKN). The ratio between net nitrate produced and the net ammonium consumed in the aerobic zone $\left(\mathrm{R}_{\mathrm{NatAmm}}\right)$ could be considered as controlled variable, since it approximates the ratio between NOB and aerobic AOB activity with a relatively high correlation coefficient, as shown in Figure 8. 


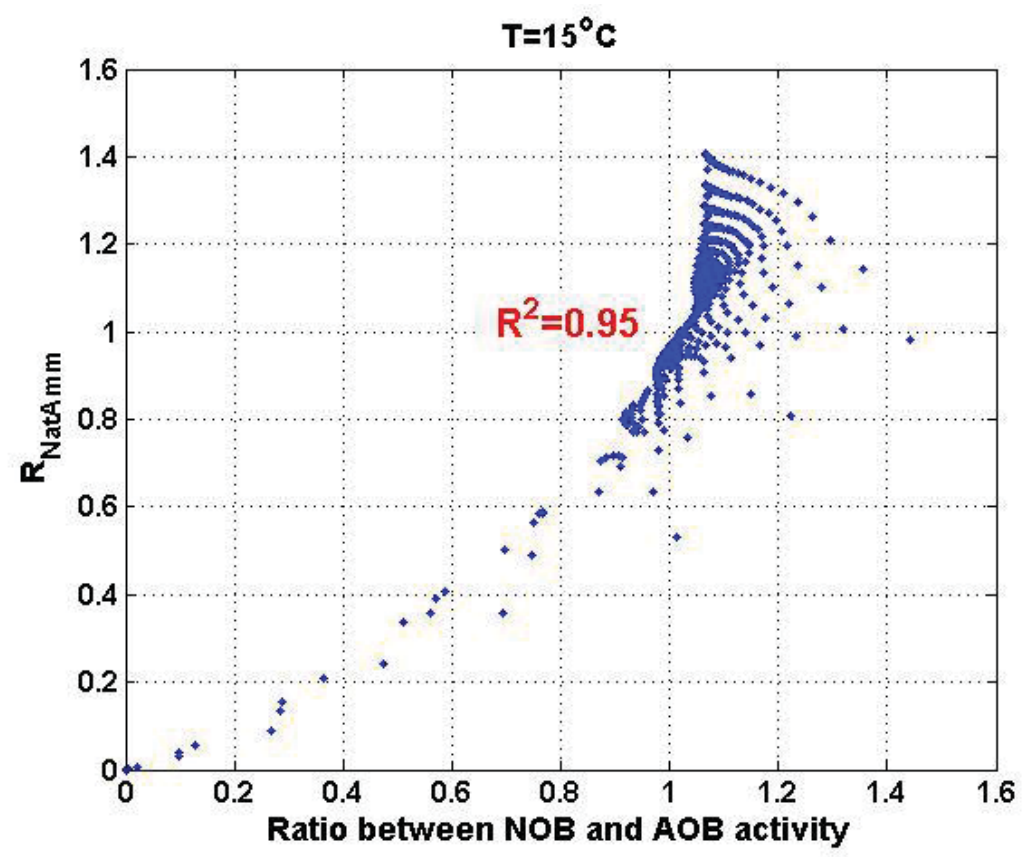

Figure 8: Ratio between NOB and $A O B$ activity against $\mathrm{R}_{\mathrm{NatAmm}}$ at a temperature of $15^{\circ} \mathrm{C}$.

Values of $\mathrm{R}_{\mathrm{NatAmm}}$ larger than 1 originate partly from the conversion of influent organic nitrogen into nitrate when the autotrophic bacteria are provided abundantly with oxygen. However, values of $\mathrm{R}_{\mathrm{NatAmm}}$ significantly higher than one can be attributed to a loss of heterotrophic biomass. More specifically, looking at Figure 9 depicting the difference between the concentration of heterotrophs in inflow and outflow of the aerobic zone, it can be noted that this quantity increases with RO. This means that, as RO increases, there is an overall decay of heterotrophs in the aerated zone, which releases organic nitrogen. This last compound is easily converted into nitrate by the autotrophic biomass and causes values of $\mathrm{R}_{\mathrm{NatAmm}}$ that are significantly higher than 1. 


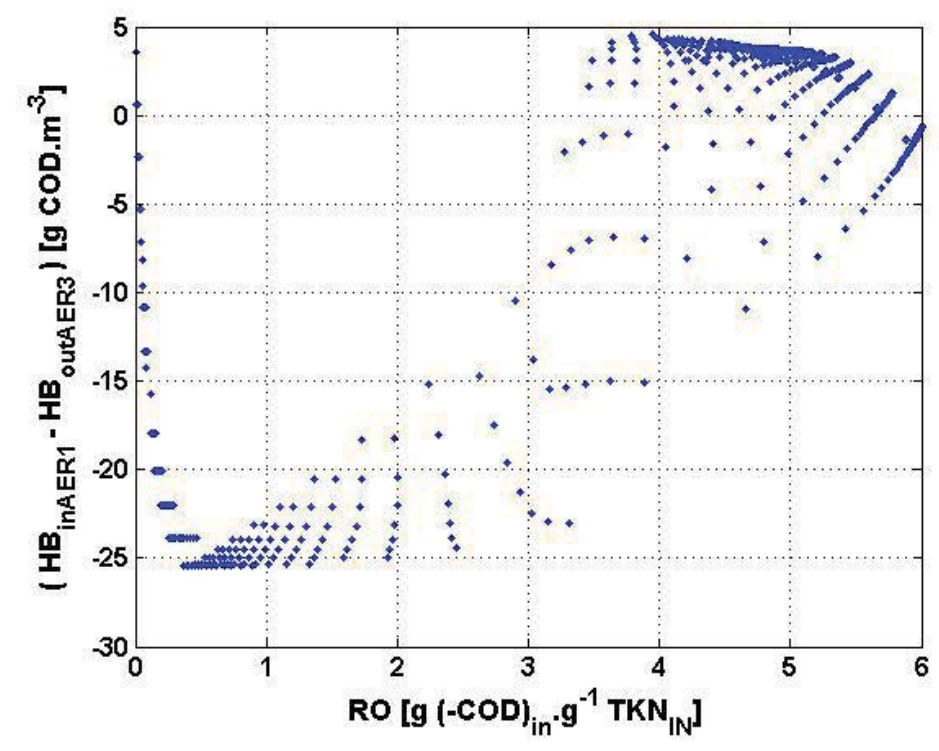

Figure 9: Difference between HB concentration in inflow and outflow to the aerobic zone.

The need for a control loop limiting the amount of oxygen carried from the aerobic to the anoxic zone could be considered as well.

While minimizing $\mathrm{N}_{2} \mathrm{O}$ emissions and respecting the effluent limits, operating costs also have to be considered for real applications. The specific oxygen consumption, indicating the amount of oxygen consumed per unit of TN removed, has identified NOB activity to decrease the economic efficiency of the plant and reduce the TN removal efficiency by requiring more organic carbon for heterotrophic denitrification. However, having high NOB activity is identified as the key for preventing $\mathrm{N}_{2} \mathrm{O}$ production. In this case, a trade-off between operational costs versus $\mathrm{N}_{2} \mathrm{O}$ emissions has to be taken in view of the objectives which the WWTP managers want to prioritize. In any case, increasing the aeration is beneficial to both the $\mathrm{N}_{2} \mathrm{O}$ emissions and the effluent quality until a certain threshold, above which the effluent quality gets worse and $\mathrm{N}_{2} \mathrm{O}$ emissions do not further reduce. To calculate this critical aeration level an appropriate process control technology needs to be developed, which has been addressed in a study for which a patent has been filed [38]. 


\section{Conclusions and future perspectives}

The main novelties of the present work can be summarized as follows:

- sensitivity analyses have been used to deduce an idea for a control strategy. As a matter of fact, sensitivity analyses, since they provide the most influential operating conditions on the variable analysed, can indicate what the most important processes are determining the value of such a variable, as well as point towards the ideal operating conditions to be manipulated for the achievement of the control objectives. This work can be used for other applications where the multitude of processes makes the identification of the optimal control strategy difficult;

- the predictive reliability of the ASMG1 with respect to $\mathrm{N}_{2} \mathrm{O}$ has been checked by comparison to findings from full-scale and lab-scale measurements. It was found that the ASMG1 can be considered to describe several $\mathrm{N}_{2} \mathrm{O}$ dynamics found in literature. This is an important finding which gives the green light for the use of the model for other purposes;

- The results of the sensitivity analyses performed by perturbing the ASMG1 parameters can be exploited to direct future calibrations of the ASMG1 according to measurements from specific WWTPs;

- $\quad \mathrm{NOB}$ activity is the main biological process determining $\mathrm{N}_{2} \mathrm{O}$ emissions. Section 3.4 has showed experiences in both full-scale and lab-scale confirming this finding. The role of NOB activity in determining $\mathrm{N}_{2} \mathrm{O}$ emissions has not been clearly stated in any of the research done till now;

- The results from the sensitivity analyses suggest that modelling NOB activity correctly is quite important for the correct prediction of $\mathrm{N}_{2} \mathrm{O}$ emissions. Till now, it has been a common practice to model $\mathrm{N}_{2} \mathrm{O}$ production by focusing on $\mathrm{AOB}$ processes while poor emphasis has been given to the modelling of NOB activity [24,40-42,15];

- A novel control idea has been derived based on the sensitivity analysis results. This control strategy has been already tested in multiple model scenarios as shown in Boiocchi [43] and has also been patented [38]. Although some adaptations may be required, the control idea formulated is expected to be effective in reducing $\mathrm{N}_{2} \mathrm{O}$ production and consequent emissions. 
One of the aspects which should be investigated further is the effect of Sludge Retention Time (SRT) on the $\mathrm{N}_{2} \mathrm{O}$ emissions. As a matter of fact, it was found that increasing the SRT of the plant would increase the relative activities of $\mathrm{NOB}$ over $\mathrm{AOB}$ and thus reduce nitrite accumulation and the consequent $\mathrm{N}_{2} \mathrm{O}$ production [44]. It is however worth to point out that the SRT is largely determined by the design of the plant and that only small variations of the same can be achieved through optimal manipulation of the wastage flow rate. A separate investigation has to be therefore carried out to quantify how possible changes of SRT can impact $\mathrm{N}_{2} \mathrm{O}$ emissions. Furthermore, SRT manipulation will need to be coupled with an oxygen regulation controller because oxygen availability will need to be larger as the nitrifying population grows up.

\section{Acknowledgement}

The work has been funded in part by the Innovation Fund Denmark (IFD) (Project LaGAS, File No. 060300523B), and Veolia Water Technologies (Krüger, AnoxKaldnes, The Veolia Group). Support from the wastewater utilities (Biofos, DK; VA SYD, SE; Lyngby-Taarbæk forsyning, DK; FORS A/S, DK; Växjö, SE) and Unisense Environment, DK, and Fluxsense AB, SE is acknowledged.

Dr. Ulf Jeppsson (Lund University) is acknowledged for having provided the codes of the Benchmark Simulation Model $n^{0} 2$.

\section{Bibliography}

[1] M.J. Kampschreur, H. Temmink, R. Kleerebezem, M.S.M. Jetten, M.C.M. van Loosdrecht, Nitrous oxide emission during wastewater treatment, Water Res. 43 (2009) 4093-4103. doi:10.1016/j.watres.2009.03.001.

[2] A. Aboobakar, E. Cartmell, T. Stephenson, M. Jones, P. Vale, G. Dotro, Nitrous oxide emissions and dissolved oxygen profiling in a full-scale nitrifying activated sludge treatment plant, Water Res. 47 (2013) 524-534. doi:10.1016/j.watres.2012.10.004.

[3] R. v. Schulthess, M. Kühni, W. Gujer, Release of nitric and nitrous oxides from denitrifying activated sludge, Water Res. 29 (1995) 215-226.

[4] J. Foley, D. de Haas, Z. Yuan, P. Lant, Nitrous oxide generation in full-scale biological nutrient removal wastewater treatment plants., Water Res. 44 (2010) 831-44. 
doi:10.1016/j.watres.2009.10.033.

[5] X. Zhu, Y. Chen, H. Chen, X. Li, Y. Peng, S. Wang, Minimizing nitrous oxide in biological nutrient removal from municipal wastewater by controlling copper ion concentrations, Appl. Microbiol. Biotechnol. 97 (2013) 1325-1334. doi:10.1007/s00253-012-3988-1.

[6] J.H. Ahn, S. Kim, H. Park, B. Rahm, K. Pagilla, K. Chandran, N2O emissions from activated sludge processes, 2008-2009: results of a national monitoring survey in the United States., Environ. Sci. Technol. 44 (2010) 4505-4511. doi:10.1021/es903845y.

[7] R. Boiocchi, K.V. Gernaey, G. Sin, Extending the benchmark simulation model $n^{\circ} 2$ with processes for nitrous oxide production and side-stream nitrogen removal, 2015. doi:10.1016/B978-0-44463576-1.50107-2.

[8] U. Jeppsson, M.-N. Pons, I. Nopens, J. Alex, J.B. Copp, K. V Gernaey, C. Rosen, J.-P. Steyer, P. a Vanrolleghem, Benchmark simulation model no 2: general protocol and exploratory case studies., Water Sci. Technol. 56 (2007) 67-78. doi:10.2166/wst.2007.604.

[9] L. Guo, P.A. Vanrolleghem, Calibration and validation of an activated sludge model for greenhouse gases no. 1 (ASMG1): prediction of temperature-dependent N2O emission dynamics., Bioprocess Biosyst. Eng. 37 (2014) 151-163. doi:10.1007/s00449-013-0978-3.

[10] K. V. Gernaey, X. Flores-Alsina, C. Rosen, L. Benedetti, U. Jeppsson, Dynamic influent pollutant disturbance scenario generation using a phenomenological modelling approach, Environ. Model. Softw. 26 (2011) 1255-1267. doi:10.1016/j.envsoft.2011.06.001.

[11] W.C. Hiatt, C.P.L. Grady, An updated process model for carbon oxidation, nitrification, and $\begin{array}{llllll}\text { denitrification., } & \text { Water } & \text { Environ. } & \text { Res. } & 80 & \text { (2008) }\end{array}$ http://www.ncbi.nlm.nih.gov/pubmed/19024730.

[12] K.E. Mampaey, B. Beuckels, M.J. Kampschreur, R. Kleerebezem, M.C.M. van Loosdrecht, E.I.P. Volcke, Modelling nitrous and nitric oxide emissions by autotrophic ammonia-oxidizing bacteria, Environ. Technol. 34 (2013) 1555-1566. doi:10.1080/09593330.2012.758666.

[13] M. Henze, C.P.L.G. Jr, W. Gujer, G.V.R. Marais, T. Matsuo, A general model for single-sludge wastewater treatment systems., Water Res. 21 (1987) 505-515.

[14] M. Spérandio, M. Pocquet, L. Guo, B.-J. Ni, P.A. Vanrolleghem, Z. Yuan, Evaluation of different nitrous oxide production models with four continuous long-term wastewater treatment process data series, Bioprocess Biosyst. Eng. 39 (2016) 493-510. doi:10.1007/s00449-015-1532-2.

[15] B.-J. Ni, L. Ye, Y. Law, C. Byers, Z. Yuan, Mathematical modeling of nitrous oxide (N2O) emissions from full-scale wastewater treatment plants, Environ. Sci. Technol. 47 (2013) 7795-7803. http://www.ncbi.nlm.nih.gov/pubmed/23772875\%5Cnhttp://dx.doi.org/10.1021/es4005398.

[16] L.J.P. Snip, R. Boiocchi, X. Flores-Alsina, U. Jeppsson, K.V. Gernaey, Challenges encountered when expanding activated sludge models: A case study based on N2O production, Water Sci. Technol. 70 (2014) 1251-1260. doi:10.2166/wst.2014.347.

[17] L.R. Iman, W.J. Conover, A distribution-free approach to including rank correlation among input variables, Commun. Stat. Comput. 11 (1982) 311-334.

[18] M.D. Morris, Factorial Sampling Plans for Preliminary Computational Experiments, Technometrics. 33 (1991) 161-174. doi:10.2307/1269043.

[19] G. Sin, K. V. Gernaey, Improving the Morris method for sensitivity analysis by scaling the elementary effects, in: Comput. Aided Chem. Eng., 2009: pp. 925-930. doi:10.1016/S15707946(09)70154-3.

[20] G. Sin, K. V Gernaey, M.B. Neumann, M.C.M. van Loosdrecht, W. Gujer, Global sensitivity analysis in wastewater treatment plant model applications: prioritizing sources of uncertainty., Water Res. 45 (2011) 639-651. doi:10.1016/j.watres.2010.08.025. 
[21] A.K. Vangsgaard, M. Mauricio-Iglesias, K. V Gernaey, B.F. Smets, G. Sin, Sensitivity analysis of autotrophic $\mathrm{N}$ removal by a granule based bioreactor: Influence of mass transfer versus microbial kinetics., Bioresour. Technol. 123 (2012) 230-241. doi:10.1016/j.biortech.2012.07.087.

[22] J.H. Ahn, T. Kwan, K. Chandran, Comparison of partial and full nitrification processes applied for treating high-strength nitrogen wastewaters: Microbial ecology through nitrous oxide production, Environ. Sci. Technol. 45 (2011) 2734-2740. doi:10.1021/es103534g.

[23] M.J. Kampschreur, W.R.L. van der Star, H. a. Wielders, J.W. Mulder, M.S.M. Jetten, M.C.M. van Loosdrecht, Dynamics of nitric oxide and nitrous oxide emission during full-scale reject water treatment, Water Res. 42 (2008) 812-826. doi:10.1016/j.watres.2007.08.022.

[24] B.-J. Ni, Z. Yuan, K. Chandran, P. a Vanrolleghem, S. Murthy, Evaluating four mathematical models for nitrous oxide production by autotrophic ammonia-oxidizing bacteria., Biotechnol. Bioeng. 110 (2013) 153-163. doi:10.1002/bit.24620.

[25] C. Hellinga, M.C.M. van Loosdrecht, J.J. Heijnen, Model Based Design of a Novel Process for Nitrogen Removal from Concentrated Flows, Math. Comput. Model. Dyn. Syst. 5 (1999) 351-371.

[26] Zhang TT., Z. J., Y. F., X. HJ., H. X., L. YR, Effect of temperature on pollutant removal and nitrous oxide emission of wastewater nitrogen removal system, Huan Jing Ke Xue. 33 (2012) 1283-1287.

[27] D.J. Kim, D.I. Lee, J. Keller, Effect of temperature and free ammonia on nitrification and nitrite accumulation in landfill leachate and analysis of its nitrifying bacterial community by FISH, Bioresour. Technol. 97 (2006) 459-468. doi:10.1016/j.biortech.2005.03.032.

[28] S. Sun, Z. Bao, D. Sun, Study on emission characteristics and reduction strategy of nitrous oxide during wastewater treatment by different processes, Environ. Sci. Pollut. Res. 22 (2014) 4222-4229. doi:10.1007/s11356-014-3654-5.

[29] M.R.J. Daelman, E.M. van Voorthuizen, U.G.J.M. van Dongen, E.I.P. Volcke, M.C.M. van Loosdrecht, Seasonal and diurnal variability of N2O emissions from a full-scale municipal wastewater treatment plant, Sci. Total Environ. $536 \quad$ (2015) 1-11. doi:10.1016/j.scitotenv.2015.06.122.

[30] F. Stenström, K. Tjus, J. la C. Jansen, Oxygen-induced dynamics of nitrous oxide in water and offgas during the treatment of digester supernatant, Water Sci. Technol. 69 (2014) 84-91. doi:10.2166/wst.2013.558.

[31] L. Peng, B.-J. Ni, D. Erler, L. Ye, Z. Yuan, The combined effect of dissolved oxygen and nitrite on $\mathrm{N} 2 \mathrm{O}$ production by ammonia oxidizing bacteria in an enriched nitrifying sludge, Water Res. 73 (2015) 29-36. doi:10.1016/j.watres.2014.08.009.

[32] L. Peng, B.-J. Ni, D. Erler, L. Ye, Z. Yuan, The effect of dissolved oxygen on N2O production by ammonia-oxidizing bacteria in an enriched nitrifying sludge, Water Res. 66 (2014) 12-21. doi:10.1016/j.watres.2014.08.009.

[33] G. Tallec, J. Garnier, G. Billen, M. Gousailles, Nitrous oxide emissions from denitrifying activated sludge of urban wastewater treatment plants, under anoxia and low oxygenation, Bioresour. Technol. 99 (2008) 2200-2209. doi:10.1016/j.biortech.2007.05.025.

[34] G. Tallec, J. Garnier, G. Billen, M. Gousailles, Nitrous oxide emissions from secondary activated sludge in nitrifying conditions of urban wastewater treatment plants: Effect of oxygenation level, Water Res. 40 (2006) 2972-2980. doi:10.1016/j.watres.2006.05.037.

[35] P. Wunderlin, J. Mohn, A. Joss, L. Emmenegger, H. Siegrist, Mechanisms of N2O production in biological wastewater treatment under nitrifying and denitrifying conditions, Water Res. 46 (2012) 1027-1037. doi:10.1016/j.watres.2011.11.080.

[36] M.J. Kampschreur, N.C.G. Tan, R. Kleerebezem, C. Picioreanu, M.S.M. Jetten, M.C.M. Van Loosdrecht, Effect of dynamic process conditions on nitrogen oxides emission from a nitrifying culture, Environ. Sci. Technol. 42 (2008) 429-435. doi:10.1021/es071667p. 
[37] V. Rassamee, C. Sattayatewa, K. Pagilla, K. Chandran, Effect of oxic and anoxic conditions on nitrous oxide emissions from nitrification and denitrification processes, Biotechnol. Bioeng. 108 (2011) 2036-2045. doi:10.1002/bit.23147.

[38] R. Boiocchi, G. Sin, K. V. Gernaey, Control of N2O-emissions by aeration (Patent $\mathrm{n}^{\circ}$ 81602701DK00), Technical University of Denmark, Kgs. Lyngby, Denmark (2016).

[39] D.E. Seborg, T.F. Edgar, D.A. Mellichamp, Process dynamics and control, 2004.

[40] B.-J. Ni, M. Ruscalleda, C. Pellicer-Nàcher, B.F. Smets, Modeling nitrous oxide production during biological nitrogen removal via nitrification and denitrification: extensions to the general asm models, Environ. Sci. Technol. 45 (2011) 7768-7776. doi:10.1021/es404125v.

[41] Y. Law, B.-J. Ni, P. Lant, Z. Yuan, N2O production rate of an enriched ammonia-oxidising bacteria culture exponentially correlates to its ammonia oxidation rate, Water Res. 46 (2012) 3409-3419. doi:10.1016/j.watres.2012.03.043.

[42] M. Pocquet, Z. Wu, I. Queinnec, M. Spérandio, A two pathway model for N2O emissions by ammonium oxidizing bacteria supported by the NO/N2O variation., Water Res. 88 (2015) 948-959. doi:10.1016/j.watres.2015.11.029.

[43] R. Boiocchi, Plant-wide modelling and control of N2O emissions from wastewater treatment plants (PhD dissertation), Technical University of Denmark, Kgs. Lyngby, Denmark (2016).

[44] P. Regmi, M.W. Miller, B. Holgate, R. Bunce, H. Park, K. Chandran, B. Wett, S. Murthy, C.B. Bott, Control of aeration, aerobic SRT and COD input for mainstream nitritation/denitritation, Water Res. 57 (2014) 162-171. doi:10.1016/j.watres.2014.03.035. 